\title{
Systematic Analysis of Transmitter Coexpression Reveals Organizing Principles of Local Interneuron Heterogeneity
}

\author{
[Dristyn M. Lizbinski, ${ }^{-1}$ Gary Marsat, and ${ }^{-1}$ Andrew M. Dacks
}

https://doi.org/10.1523/ENEURO.0212-18.2018

Department of Biology, West Virginia University, Morgantown, WV 26505

\begin{abstract}
Broad neuronal classes are surprisingly heterogeneous across many parameters, and subclasses often exhibit partially overlapping traits including transmitter coexpression. However, the extent to which transmitter coexpression occurs in predictable, consistent patterns is unknown. Here, we demonstrate that pairwise coexpression of GABA and multiple neuropeptide families by olfactory local interneurons (LNs) of the moth Manduca sexta is highly heterogeneous, with a single LN capable of expressing neuropeptides from at least four peptide families and few instances in which neuropeptides are consistently coexpressed. Using computational modeling, we demonstrate that observed coexpression patterns cannot be explained by independent probabilities of expression of each neuropeptide. Our analyses point to three organizing principles that, once taken into consideration, allow replication of overall coexpression structure: (1) peptidergic neurons are highly likely to coexpress GABA; (2) expression probability of allatotropin depends on myoinhibitory peptide expression; and (3) the all-or-none coexpression patterns of tachykinin neurons with several other neuropeptides. For other peptide pairs, the presence of one peptide was not predictive of the presence of the other, and coexpression probability could be replicated by independent probabilities. The stochastic nature of these coexpression patterns highlights the heterogeneity of transmitter content among LNs and argues against clear-cut definition of subpopulation types based on the presence of single neuropeptides. Furthermore, the receptors for all neuropeptides and GABA were expressed within each population of principal neuron type in the antennal lobe (AL). Thus, activation of any given $L N$ results in a dynamic cocktail of modulators that have the potential to influence every level of olfactory processing within the AL.
\end{abstract}

Key words: Cotransmission; heterogeneity; local interneurons; neuropeptides

\section{Significance Statement}

Understanding the functional roles of individual local interneurons (LNs) is complex because traits, like transmitter coexpression, are often partially overlapping across the population. Here, we find that single olfactory LNs coexpress neuropeptides from at least four individual peptide families, and that GABA and neuropeptides are partially and heterogeneously coexpressed across the entire population. The stochastic nature of many observed coexpression patterns argues against clear-cut and exclusive definition of subpopulations based on the expression of single neuropeptides. Overall, our results suggest that activation of any given LN causes the release of a variable combination of neuropeptides and GABA that, based on receptor expression, target the input, output, and local processing stages of olfactory coding.

Received May 28, 2018; accepted September 13, 2018; First published September 21, 2018.

The authors declare no competing financial interests.
Author contributions: All authors had full access to all the data in the study and take responsibility for the integrity of the data and the accuracy of the data analysis. Study concept and design: Kristyn M. Lizbinski (KML), Gary Marsat 


\section{Introduction}

The historical concept of a cell type, propelled by the work of Cajal (1995) and Golgi (1906), suggests that distinct functional classes of neurons can be identified based on their morphology (Ramón et al., 1972; Shepherd, 2015). Yet recent advances in transcriptomics and electrophysiology have revealed that even neurons within a single cell type can still be surprisingly heterogeneous in their synaptic, biophysical, and transcriptional profiles (Cohen et al., 2015; Eddine et al., 2015; Okaty et al., 2015; $\mathrm{Li}$ et al., 2017). Local interneurons (LNs) tend to be particularly heterogeneous across many parameters, leading to the identification of numerous LN subtypes within cortex (Flames and Marín, 2005; DeFelipe et al., 2013; Yavorska and Wehr, 2016), hippocampus (Maccaferri and Lacaille, 2003), and spinal cord (Gabitto et al., 2016; Sweeney et al., 2018). For example, two spinal interneuron populations that support different motor output (limb vs thoracic) can be distinguished, and further subdivided, based on transcription factor expression profile (Sweeney et al., 2018). Similarly, 13 distinct groups of GABAergic cortical interneurons exhibit partially overlapping expression of multiple neuropeptides and modulators (Gonchar et al., 2007). Thus, parameters used to classify LN subpopulations can be partially overlapping across functionally distinct subpopulations. Consequently, attempting to assign a unified functional role to subpopulations based on single molecular markers or transmitters is misleading. How then, do we reconcile heterogeneity within cell types?

To determine the organizing principles that govern neuronal heterogeneity, it is critical to use a combinatorial approach, which takes multiple parameters, such as transmitter coexpression, into consideration. The insect antennal lobe (AL), analogous to the olfactory bulb, is an excellent system in which to approach this problem owing to the wealth of information on local interneuron physiol-

(GM), Andrew M. Dacks (AMD). Acquisition of data: KML Computational model: KML, GM. Analysis and interpretation of data: KML, GM, AMD. Drafting of the manuscript: KML, GM, AMD. Critical revision of the manuscript for important intellectual content: KML, GM, AMD. Obtained funding: AMD. Administrative, technical, and material support: AMD. Study supervision: AMD.

This work was supported by an R03 DC013997-01 from the $\mathrm{NIH}$, and USAFOSR FA9550-17-1-0117 to AMD, as well as a National Science Foundation grant IOS-1557846 to GM.

Acknowledgments: We thank Dr. Tim Driscoll and Dr. Tori Verhoeve for their advice and help with RT-qPCR experimental design and setup, Andrew Steele and Lillian Bailey for their help with cell counts, and Aditya Kesari for assistance with preliminary data as well as the other members of the Dacks lab for their support. We also thank Kate Allen, Tyler Sizemore, Philip Chapman, Dr. Kevin Daly, Dr. Sadie Bergeron, Dr. Quentin Gaudry, and Dr. Mani Ramaswami for helpful comments on this manuscript. The TK, AST-A, and Mas-AT antibodies were provided by Dr. Jan Veenstra, the MIP antibody was provided by Dr. Christian Wegener and developed by Dr. Manfred Eckert, and the FMRF antibody by Dr. Eve Marder.

Address correspondence to either of the following: Kristyn M Lizbinski at the above address, E-mail: lizbinskik2@gmail.com; or Andrew M. Dacks, P.O. Box 6057 Morgantown, WV 26506. E-mail: andrew.dacks@mail.wvu.edu.

https://doi.org/10.1523/ENEURO.0212-18.2018

Copyright (C) 2018 Lizbinski et al.

This is an open-access article distributed under the terms of the Creative Commons Attribution 4.0 International license, which permits unrestricted use, distribution and reproduction in any medium provided that the original work is properly attributed. ogy, morphology, and transmitter content combined with its relative numerical simplicity. The olfactory system detects and transforms odor input into meaningful output, ultimately informing an animal's choice to mate, seek food, or avoid predators (Ache and Young, 2005). Odorants are first detected by olfactory receptor neurons (ORNs), which synapse onto projection neurons (PNs) within substructures called glomeruli that form an odortopic map within the AL. The input/output relationship between ORNs and PNs is refined by a diverse population of LNs that transform odor information via a variety of mechanisms (Wilson, 2013). In Manduca sexta, LNs are primarily inhibitory (Christensen et al., 1993), broadly tuned to odorants, exhibit both inhibitory and excitatory responses, and are highly morphologically and physiologically diverse (Hildebrand et al., 1992; Reisenman et al., 2011). However, there are no correlations between morphology, physiology, and GABA expression in Manduca LNs (Reisenman et al., 2011), suggesting a high degree of heterogeneity within this population. Furthermore, in Manduca, as well as other insects, AL LNs express a combination of GABA and multiple neuropeptides (Homberg et al., 1990; Schachtner et al., 2004; Utz et al., 2007, 2008; Reisenman et al., 2011; Fusca et al., 2015). Consequently, understanding the functional roles of individual LNs is complex, as we lack a systematic analysis of transmitter coexpression (Nässel, 2018).

We used the olfactory system of Manduca to determine if subclasses of LNs have common transmitter profiles. We characterized each pairwise coexpression pattern for GABA and five neuropeptides and found that although almost all peptidergic LNs coexpress GABA, neuropeptide coexpression is heterogeneous across LNs. Using computational modeling, we demonstrate that many coexpression patterns cannot be explained by independent probabilities of expression of each peptide, highlighting that certain pairs of peptides co-occur more (or less) often than by chance. For other pairs, the presence of one peptide was not predictive of the presence of the other, and coexpression probability could be replicated by independent probabilities. The stochastic nature of these coexpression patterns highlights the heterogeneity of transmitter content among LNs and argues against clearcut and exclusive definition of subpopulation types based on the presence of a single neuropeptide. One possible explanation for this heterogeneity is that principal cell classes within the AL express different GABA and neuropeptide receptors. This would segregate the influence of each modulator across different cell types (Nusbaum et al., 2001, 2017; Tritsch et al., 2016), as is the case for the clock network of Drosophila melanogaster (Liang et al., 2017). However, this is not likely to be the case here, as all neuropeptide and $G A B A_{B}$ receptors were expressed within every cell class of the AL (ORNs, PNs, and LNs). Overall, our results suggest that activation of any given $\mathrm{LN}$ likely releases a variable combination of peptides and GABA to potentially influence every cell class within the AL. 


\section{Materials and Methods}

\section{Animals}

Manduca sexta were raised at West Virginia University as previously described (Bell and Joachim, 1976; Daly et al., 2013). Equal numbers of unmated adult males and female moths were pooled for all data.

\section{Immunocytochemistry}

Brains were dissected in physiological saline (Christensen and Hildebrand, 1987), fixed in 4\% paraformaldehyde overnight at $4{ }^{\circ} \mathrm{C}$, and embedded in $5 \%$ agarose to be sectioned at $100 \mu \mathrm{m}$ using a Leica VT $1000 \mathrm{~S}$ vibratome. Sections were washed in PBS with 1\% Triton $X-100$ (PBST), blocked in PBST and 2\% immunoglobulin G (lgG)-free BSA (Jackson Immunoresearch; Cat\# 001000-161), and then incubated in blocking solution with 5 $\mathrm{mm}$ sodium azide and primary antibodies. For all rabbitneuropeptide/mouse-GABA protocols, sectioned tissue was incubated for $48 \mathrm{~h}$ at dilutions of 1:3000 and 1:500, respectively. Sections were then briefly washed with PBS and PBST, cleared with ascending glycerol washes, and then mounted on slides with Vectashield (Vector Laboratories; Cat\# H-1000). All neuropeptide antibodies used in this study were raised in rabbit. For protocols in which we labeled with two antisera raised in rabbit, we used APEX Antibody Labeling Kits 488, 555, 647 (Invitrogen; Cat\# A10468, A10470, A10475, respectively) to directly attach a fluorophore with excitation/emission spectra at different wavelengths to each primary to avoid cross-labeling from a secondary antibody (Bradley et al., 2016). Using the resin tip from the APEX kit, a small amount of the antibody $(10-20 \mu \mathrm{g})$ was pushed through the resin using an elution syringe, and the reactive dye was prepared using DMSO and a labeling buffer (solutions provided in APEX kit). The reactive dye was eluted through the tip onto the antibody remaining in the resin to covalently bond the fluorescent label to the IgG antibodies. The tip was incubated overnight $4^{\circ} \mathrm{C}$ or at room temperature for $2 \mathrm{~h}$, and the labeled product was eluted through the tip. Resulting labeled antibody volume of $50 \mu \mathrm{l}$ in a total volume of $2400 \mu \mathrm{l}$ was used to label 6 brains at equal dilution of $400 \mu \mathrm{l}$ per well and incubated for $72 \mathrm{~h}$ in $3 \%$ Triton $\mathrm{X}-100$ with PBSAT. Sections were then washed and mounted as above.

\section{Antibody characterization}

Specificity controls (including pre-adsorption controls) for the allatostatin-A (AST-A), allatotropin (Mas-AT), tachykinin (TK), and myoinhibitory peptide (MIP) antibodies in Manduca brain tissue are described completely in Lizbinski et al. (2016). GABA pre-adsorption controls in Manduca AL tissue for the mouse GABA antiserum are described in Bradley et al. (2016). The antibodies used in this study likely cross-react with several isoforms within the same peptide family. Thus, our results can only resolve principles at the level of peptide family and not individual peptide isoforms.

GABA: The GABA antibody (Sigma Aldrich, cat\# A2052) was raised in rabbit against GABA coupled to BSA with paraformaldehyde. MIP: Antiserum raised in rabbit against MIP conjugated to thyroglobulin was produced by M. Eck- ert, Jena, Germany, and provided by C. Wegener, Marburg, Germany (Predel et al., 2001; RRID: AB_2314803). Mas-AT: Antiserum raised in rabbit against Manduca allatotropin (Mas-AT) was kindly provided by Dr. J. Veenstra, University of Bordeaux, Talence, France (Veenstra and Hagedorn, 1995; RRID: AB_2313973). AST-A: Antiserum was raised (Reichwald et al., 1994) in rabbit against octadecapeptideallatostatin (Pratt et al., 1991), ASB2 (AYSYVSEYKALPVYNFGL-NH2) of Diploptera punctata, and kindly provided by Dr. J. Veenstra. It recognizes AKSYNFGLamide, a form of AST and other AST-like peptides. TK: Antiserum raised in rabbit against locust tachykinin II with bovine thyroglobulin with glutaraldehyde was kindly provided to us by Dr. J. Veenstra (RRID: AB_2341129). FMRF: FMRFamide antiserum was raised against synthetic RF-amide coupled to bovine thyroglobulin with glutaraldehyde and provided by Dr. Eve Marder (Marder et al., 1987). Pre-adsorption controls of the antiserum against synthetic FMRFamide eliminated labeling in larval Manduca nervous tissue (Witten and Truman, 1996).

\section{Confocal microscopy}

Image stacks were scanned using an Olympus Fluoview FV1000 confocal microscope with argon and green and red HeNe lasers. Scans were taken at either $800 \times$ 800 - or $1024 \times 1024$-pixel resolution, $1.5 \mu \mathrm{m}$ between optical sections, using both $20 \times / 0.80$ Oil UPlanApo and $40 \times / 1.30$ Oil $\infty$ 0.17/FN 26.5, $80 \mu \mathrm{m}$ pinhole size, Olympus lenses. Fluoview (FV10-ASW Viewer software, v.4.2b) was also used to set brightness levels, and Corel Draw X4 was used to organize figures.

\section{Cell counts and coexpression}

Images of immunostained brains were exported as .tiff stacks in Fluoview software. Stacks were then imported into VAA3D software (available at https://github.com/ Vaa3D/release/releases/; Peng et al., 2010, 2014a,b; Bria et al., 2016) to determine individual cell counts and coexpression cell counts. The number of local interneurons in the lateral cell cluster that express each transmitter were counted in VAA3D ( $n=6$ brains per label combination, 3 brains per sex). We used cell body size and location within the lateral cell cluster to distinguish between LNs and PNs (Homberg et al., 1988). The average and standard deviation of number of cells per $\mathrm{AL}$ that expressed a given transmitter were calculated for each combination. Wilcoxon rank sum tests were performed using Prism v.5.01 (GraphPad) to determine if there was any significant difference between the left and the right $A L$ for each brain. Coexpression ratios were determined by dividing the number of cells expressing both an individual neuropeptide and GABA by the total number of cells expressing just the neuropeptide and calculated in Excel. Neuropeptide coexpression ratios were determined in the same manner for every possible pairwise combination using data from peptides stained using the APEX kits. FMRF/MIP coexpression ratios were not calculated, as the APEX kits labeled significantly fewer MIP neurons than all other runs, and therefore the ratios would not have reflected accurate coexpression. Thus, FMRF/MIP coexpression was not used in subsequent models or computational analysis as a constraint or a relationship to replicate. All 
Table 1. Neuropeptide cell body totals and percentage coexpression with GABA

\begin{tabular}{lll}
\hline & $\begin{array}{l}\text { Average no. } \\
\text { of cell bodies } \\
\text { in lateral cell }\end{array}$ & \\
Neuropeptide & cluster & \% coexpression \\
TK & $12.16 \pm 0.55$ & 84.6 \\
FMRF & $58.16 \pm 17.48$ & 92.8 \\
Mas-AT & $143.58 \pm 24.38$ & 97.2 \\
MIP & $150.66 \pm 16.79$ & 97.5 \\
AST-A & $47.4 \pm 12.83$ & 96.7
\end{tabular}

other neuropeptide/neuropeptide coexpression experiments labeled an accurate number of cell bodies when compared to cell counts from GABA/neuropeptide runs using indirect immunocytochemistry. Cell count totals and standard deviations from APEX kit labeling (Fig. 2) were used in all model iterations, as coexpression ratios were calculated using that data.

\section{Putative neuropeptide receptor sequence BLAST}

We used receptor sequences from closely related invertebrate species to identify putative sequence homologs on Manduca scaffolds. Protein sequences from Drosophila and other closely related species were identified by annotation (see Table 2) and queried against the Manduca genome using tblastn (National Agricultural Library, i5k initiative, https://i5k.nal.usda.gov/Manduca_sexta). Top matches to each receptor sequence in Manduca were subsequently queried against the NCBI nr database to confirm their putative annotation as Manduca receptor homologs. These sequences were used for primer design for RT-qPCR analysis of putative neuropep- tide receptor expression in the antennae, medial and lateral cell clusters, and brain. Sequences that were previously identified in Manduca for Mas-ATr and RpS3 (Jiang et al., 1996; Horodyski et al., 2011) were downloaded as FASTA files from NCBI (http://www.ncbi.nlm.nih.gov/ gene/?term $=$ ) and used to design RT-qPCR primers. Open reading frames were established using ORF Finder at https://www.ncbi.nlm.nih.gov/orffinder/. A recent study partially annotated the Manduca genome (Kanost et al., 2016). We used the Manduca raw sequence and assembled genome sequence at NCBI Assembly ID GCA_000262585 from Kanost (http://www.ncbi.nlm.nih.gov/assembly/ GCA_000262585.1; Kanost et al., 2016) and identified the sequence IDs for each of the transcripts in question (Table 1). None of the putative receptor sequences are currently annotated in NCBI Assembly ID GCA_000262585.

\section{Primer design}

Open reading frame nucleotide sequences for each receptor, as established above, were used as the basis for primer design for RT-qPCR. Primers were designed using https://www.idtdna.com/calc/Analyzer/Home/ Instructions and checked for optimal conditions using OligoAnalyzer 3.1 (https://www.idtdna.com/calc/analyzer). Primers and amplicons were then run through a BLAST of the Manduca genome to determine if they matched to the specified sequence and to rule out potential priming mismatches with other parts of the genome. Table 2 lists primer sequences and annealing temperatures. All primers used for RT-qPCR amplified a 90-125-bp stretch of sequence.

\section{Real-time quantitative PCR (RT qPCR)}

Antennae, medial cell clusters, lateral cell clusters, and brains were collected from 2-6-d-old, unmated, naive

Table 2. BLAST results for neuropeptide receptor primer design and primer sequences

\begin{tabular}{|c|c|c|c|c|c|c|}
\hline \multirow[b]{2}{*}{ Receptor } & \multirow{2}{*}{$\begin{array}{l}\text { Accession no. } \\
\text { of sequence for } \\
\text { forward BLAST and } \\
\text { origin species }\end{array}$} & \multirow[b]{2}{*}{$\begin{array}{l}\text { Returned } M \text {. sexta } \\
\text { subject sequence } \\
\text { ID and E value }\end{array}$} & \multirow[b]{2}{*}{$\begin{array}{l}\text { Accession no. } \\
\text { of reverse BLAST } \\
\text { top hit }\end{array}$} & \multicolumn{2}{|l|}{ Primer sequences } & \multirow[b]{2}{*}{$\begin{array}{l}\text { Annealing } \\
\text { temp. }\left({ }^{\circ} \mathrm{C}\right)\end{array}$} \\
\hline & & & & Forward & Reverse & \\
\hline$\overline{\mathrm{TKr}}$ & $\begin{array}{r}\text { AAA28722.1 }(D . \\
\text { melanogaster) }\end{array}$ & $\begin{array}{l}\text { Msex2.00568-RA scaffold00007: } \\
\text { 996602-1079056(+); } \\
\text { JH668285.1; E value: e-103 }\end{array}$ & $\begin{array}{l}\text { NP_001127749.1 (Bombyx } \\
\text { mori) }\end{array}$ & ACAGGTACGTGGCGATAGTG & AGCTGGCACACCAAACAGTA & 58.3 \\
\hline FMRFr & $\begin{array}{l}\text { AHN57950.1 }(D . \\
\text { melanogaster) }\end{array}$ & $\begin{array}{l}\text { Msex2.13475-RA scaffold01034: } \\
\text { 41471-49046(+); } \\
\text { JH669301.1; E value: 2e-77 }\end{array}$ & $\begin{array}{l}\text { NP_001037007.1 (Bombyx } \\
\text { mori) }\end{array}$ & АCCGTGCTCATCCTTACCTC & TGCGGACACACGTGATAGTA & 58.3 \\
\hline ASTr & $\begin{array}{l}\text { AAG22404.3 ( } D . \\
\text { melanogaster) }\end{array}$ & $\begin{array}{l}\text { Msex2.08175-RB scaffold00218: } \\
\text { 172215-185483(-); } \\
\text { JH668496.1; E value: e-100 }\end{array}$ & $\begin{array}{l}\text { ACJ06649.1 (Spodoptera } \\
\text { littoralis) }\end{array}$ & ATCTGGCCGTAGCTGATCTT & GCATTACATAATCCGTTGCG & 58.3 \\
\hline MIPr & $\begin{array}{r}\text { NP_001108346.1 } \\
(\text { Bombyx mori) }\end{array}$ & $\begin{array}{l}\text { Msex2.12746-RA scaffold00798: } \\
\text { 532-18804(+); JH669075.1; E } \\
\text { value: e-139 }\end{array}$ & $\begin{array}{l}\text { AGE92037.1 (Spodoptera } \\
\text { litura) }\end{array}$ & GGGTTCAGGGTACTGTTCGT & GAACAGGAGCACATTCAGGA & 58.3 \\
\hline Mas-ATr & $\begin{array}{l}\text { ADX66344.1 (M. sexta; } \\
\text { Horodyski et al., } \\
\text { 2011) }\end{array}$ & JH668656.1 & N/A & TTCCTTGGAGACGTGCTGT & ACTTGAACTTGAGCGGG & 52 \\
\hline $\mathrm{GABA}_{\mathrm{B}}-\mathrm{R} 1$ & $\begin{array}{l}\text { HG004164.1 (Heliothis } \\
\text { virescens; at } \\
\text { European Nucleotide } \\
\text { Archive) }\end{array}$ & $\begin{array}{l}\text { Msex2.03321-RA scaffold00068: } \\
\text { 510618-566612(-); } \\
\text { JH668346.1; E value: } \\
0.0\end{array}$ & $\begin{array}{l}\text { XM_013339859.1 } \\
\quad \text { (Amyelois transitella) }\end{array}$ & TATTTCGGGAATGACTTCTG & TCAATATCATATCCGGCTTC & 58.3 \\
\hline RPs3 & $\begin{array}{l}\text { U12708 (M. sexta; Jiang } \\
\text { et al., 1996) }\end{array}$ & JH668297.1 & $\mathrm{N} / \mathrm{A}$ & CATGATCCACTCCGGTGAC & GACCTTAATTCCGAGCACTCC & 58.3 \\
\hline vGLUT & $\begin{array}{l}\text { FBgn0031424 ( } D . \\
\text { melanogaster; at } \\
\text { FlyBase) }\end{array}$ & JH668481; E value: $5 e-18$ & $\begin{array}{l}\text { XM_014627996.1 } \\
\text { (Dinoponera } \\
\text { quadriceps) }\end{array}$ & GACCACGACTAATGTGCGGA & CATTGAGTTGACGATCGGCG & 58.3 \\
\hline
\end{tabular}


Table 3. Cq Values for all receptors and RpS3 from RT-qPCR

\begin{tabular}{|c|c|c|c|c|c|c|c|c|c|c|c|c|c|c|}
\hline Receptor & RT or RT- & ANTa & ANTb & ANTC & $\mathrm{Ba}$ & $\mathrm{Bb}$ & $\mathrm{Bc}$ & $\mathrm{Ma}$ & $\mathrm{Mb}$ & $\mathrm{Mc}$ & $\mathrm{La}$ & $\mathrm{Lb}$ & Lc & Genomic \\
\hline \multirow[t]{2}{*}{$\mathrm{TKr}$} & RT & 0 & 34.1 & 34.5 & 31.36 & 35.35 & 29.63 & 38.51 & 32.18 & 34.03 & 39 & 0 & 37.59 & 24.09 \\
\hline & RT- & 0 & 0 & 0 & 0 & 0 & 0 & 0 & 0 & 0 & 0 & 0 & 0 & 0 (NTC) \\
\hline \multirow[t]{2}{*}{ Mas-ATr } & $\mathrm{RT}$ & 35.72 & 33.65 & 33.41 & 32.28 & 37.32 & 31.26 & 39.8 & 32.42 & 33.55 & 35.77 & 37.6 & 36.29 & 30.24 \\
\hline & RT- & 0 & 0 & 0 & 0 & 0 & 0 & 0 & 0 & 0 & 0 & 0 & 0 & 39.48 (NTC \\
\hline \multirow[t]{2}{*}{ FMRFr } & RT & 32.43 & 29.04 & 29.1 & 26.56 & 31.14 & 25.95 & 33.01 & 27.53 & 28.03 & 31.57 & 32.22 & 30.89 & 24.85 \\
\hline & RT- & 0 & 0 & 0 & 0 & 0 & 0 & 0 & 0 & 0 & 0 & 0 & 0 & 0 (NTC) \\
\hline \multirow[t]{2}{*}{ MIPr } & $\mathrm{RT}$ & 33.91 & 31.03 & 30.69 & 29.55 & 33.31 & 27.94 & 34.94 & 28.92 & 30.15 & 34.97 & 35.73 & 33.12 & 23 \\
\hline & RT- & 0 & 0 & 0 & 0 & 0 & 0 & 0 & 0 & 0 & 0 & 0 & 0 & TC) \\
\hline \multirow[t]{2}{*}{ AST-Ar } & $\mathrm{RT}$ & 37.28 & 32.23 & 31.23 & 29.26 & 23.63 & 28.17 & 37.39 & 31.19 & 32.39 & 35.43 & 37.35 & 35.14 & 25 \\
\hline & RT- & 0 & 0 & 0 & 0 & 0 & 0 & 0 & 0 & 0 & 0 & 0 & 0 & 0 (NTC) \\
\hline \multirow[t]{2}{*}{$\mathrm{GABA}_{\mathrm{B}}$} & RT & 32.21 & 29.09 & 28.62 & 27.91 & 31.17 & 25.97 & 33.48 & 27.26 & 28.51 & 33.26 & 35.51 & 31.97 & 23.72 \\
\hline & RT- & 0 & 0 & 0 & 0 & 0 & 0 & 0 & 0 & 0 & 0 & 0 & 0 & 0 (NTC) \\
\hline \multirow[t]{2}{*}{ vGlut } & $\mathrm{RT}$ & $x$ & $\mathrm{x}$ & $x$ & 24.43 & 28.40 & 23.21 & $\mathrm{x}$ & & 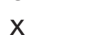 & 32.60 & 0 & 31.96 & 24.82 \\
\hline & RT- & $x$ & $x$ & $x$ & 0 & 0 & 0 & $x$ & $\lambda$ & $x$ & 0 & 0 & 0 & 0 (NTC) \\
\hline \multirow[t]{2}{*}{ RpS3 } & RT & 25.61 & 22.49 & 22.16 & 22.91 & 26.65 & 21.41 & 28.89 & 23.16 & 24.04 & 28.93 & 28.6 & 26.04 & 24.18 \\
\hline & RT- & 0 & 0 & 0 & 0 & 0 & 0 & 0 & 0 & 0 & 0 & 0 & 0 & 0 (NTC) \\
\hline \multirow[t]{2}{*}{$\operatorname{RpS} 3\left(\right.$ at $52^{\circ} \mathrm{C}$ ) } & RT & 24.54 & 21.85 & 21.87 & 23.18 & 27.04 & 21.31 & 28 & 23.21 & 24.18 & 26.68 & 28.03 & 25.23 & 18.29 \\
\hline & RT- & 4.41 & 0 & 0 & 39 & 37.27 & 0 & 37.2 & 5.13 & 28.94 & 36.16 & 38.98 & 0 & 5.23 (NTC) \\
\hline
\end{tabular}

adult Manduca, and RNA was extracted using a TRIzol reagent (Molecular Research center, Cat\# TR 118). Equal numbers of pooled males and females were used for each biological tissue sample for a total of 3 biological samples for each tissue type $(n=3$ antennae; $n=40$ medial cell clusters from 20 brains; $n=40$ medial cell clusters from 20 brains; and $n=2$ brains). We used the 40s ribosomal protein s3 (RpS3) as our reference gene. RpS3 expression values were consistent across biological replicates. RNA was treated with TURBO DNA-free Kit (Thermo Fisher Scientific, Cat\# AM1907) to prevent genomic DNA contamination, and cDNA was synthesized using the SuperScript IV First-Strand Synthesis System (Thermo Fisher Scientific, Cat\# 18091050). We performed RT qPCR with the Bio-Rad CFX Connect Real-Time System (Cat $\# 1855201$ ) to determine the relative expression of putative neuropeptide receptors across our tissue samples. Individual samples were prepared by combining prepared cDNA sample, [100 $\mu \mathrm{m}]$ forward and reverse primers, SsoFast EvaGreen Supermix (Bio-Rad, Cat\# 1725200), and nuclease-free $\mathrm{diH}_{2} \mathrm{O}$ to a volume of $10 \mu \mathrm{l}$. $\mathrm{RT}^{-}$samples, no template controls (NTCs), and positive controls with Manduca genomic DNA from the brain were run for every plate. $\mathrm{RT}^{-}$and NTC had no amplification for all receptors and sample types run at $58.3^{\circ} \mathrm{C}$ (Table 3). Optimal annealing temperatures were determined through a gradient test on genomic DNA to ensure that qPCR on cDNA was performed at optimal temperature. All primer sets, including the reference gene, RpS3, were run using the following protocol $\left[95^{\circ} \mathrm{C} 2 \min \left(95^{\circ} \mathrm{C} 5 \mathrm{~s} \rightarrow 58.3^{\circ} \mathrm{C} 30\right.\right.$ s) $\times 39$ cycles, $65.0^{\circ} \mathrm{C} 5 \mathrm{~s}$ stepped up to $95^{\circ} \mathrm{C}$ ) except for Mas-ATr primers, which were annealed at a temperature of $52^{\circ} \mathrm{C}$. All samples for RpS3 were run again at $52^{\circ} \mathrm{C}$ to ensure accurate calculation of relative expression values for Mas-ATr. Cq values for ANTa (antennae sample a), Mb (Medial cell cluster sample b), and NTC sample for the RpS3 run at $52^{\circ} \mathrm{C}$ were high (Table 3 ). However, amplification curves revealed that there were no sharp amplification peaks, and thus high $\mathrm{Cq}$ values were due to noise not contamination. High $\mathrm{Cq}$ values with nondescript peaks for RpS3 NTCs run at $52^{\circ} \mathrm{C}$ were considered 0 for $\mathrm{ANTa}, \mathrm{Mb}$, and NTC when calculating relative expression.

\section{qPCR relative expression analysis}

Raw qPCR data can be found in Table 3. Delta Ct $\left(\mathrm{Ct}_{\text {receptor }}-\mathrm{Ct}_{\text {reference gene }}\right)$ values were calculated for each receptor using RpS3 Ct values as the reference gene and averaged across all biological replicates for brain, lateral cell cluster, medial cell cluster (MCC), and antennae tissue samples. Relative expression levels $\left(2^{-\Delta \mathrm{CT}}\right)$ were calculated for all receptors. Ct values $\leq 37$ were considered nondetectable. All graphical representations for receptor qPCR were performed in GraphPad Prism (v. 5.01).

\section{Computational analysis of transmitter coexpression}

We wrote a Matlab program to determine if our observed transmitter coexpression data could be replicated by independent probabilities of expression of each transmitter. Given the known total number of LNs in the lateral cell cluster, and the total number of LNs expressing each neuropeptide from our cell counts, the model determines the probability of a given neuron coexpressing two transmitters. The program is given the average number of cells expressing a given neurotransmitter and then randomly assigns them to one of the cells in the cluster. The model can thus determine the probability of pairwise coexpression (i.e., $100 \%$ of TK cells express MIP) in the lateral cell cluster based on chance. Specifically, using our observed data as the backbone of the model, we designed a matrix with 6 columns, 1 per transmitter type (TK, FMRF, MasAT, MIP, AST-A, GABA), with a row length of 360 long (the total number of LNs in the lateral cell cluster; Homberg et al., 1988). Within each column, the model randomly distributes the number of cells that express a given transmitter to a row between 1 and 360 (Fig. 3A). For example, if we know that 12 cells within the lateral cell cluster are TKergic, the model randomly picks 12 numbers between 1 and 360 in the TK column and marks that cell as TK positive. The number of cells expressing a certain neurotransmitter is chosen probabilistically based on the ob- 
served average and standard deviation of the number of neurons that express a given transmitter. With each iteration of the model, the cells that are assigned as transmitter positive within each column are randomized. The model does this with all respective cell count totals for each transmitter column and then calculates the percentage of each transmitter's expression with another transmitter based on independent expression of each transmitter (across all pairwise comparisons). Standard deviation and percentages of coexpression were recorded across 10,000 iterations of the model. We then compared our observed coexpression percentages to the model's output to determine if independent probabilities of expression of each transmitter could explain observed coexpression.

The model described above has no initial assumption about the likelihood of coexpression, and only the overall number of cells expressing each of the transmitter is determined initially. We used a similar model to determine if assigning dependent coexpression relationships for specific pairs of transmitters could replicate the coexpression patterns for other transmitter pairs. To do this, we built certain coexpression relationships explicitly as initial assumptions. For example, if we know that on average $100 \%$ of TKergic cells are also MIPergic, the program explicitly forces $100 \%$ of the cells that are assigned to be TK positive to also be MIP positive. This coexpression relationship is thus no longer determined based on independent expression probabilities like the first version of the script, but rather is an initial assumption: a rule. We can then determine if this rule alone shifts the coexpression of other transmitter types closer to the observed coexpression percentages. We applied these rules one by one (for a total of 94 different models), for every pairwise comparison of coexpression and statistically compared the output of the independent expression model to the output of the rule-based model as well as the observed coexpression patterns we identified with immunocytochemistry. This allowed us to determine if specific coexpression relationships could replicate other coexpression relationships within LNs. The script was run on a Windows 7 desktop, with an Intel Core 17-3770 CPU @ 3.4GHz processor, and a 64-bit operating system.

\section{Code accessibility}

Custom MatLab scripts available at https://www. dacksneuroscience.com/matlab-scripts.html, at https:// github.com/lizbinskik2/co-expression-probability, or on request. The code is also available as Extended Data.

\section{Experimental design and statistical analysis}

The model outputs a predicted percentage of coexpression for every pairwise coexpression relationship. To statistically determine how well the model replicated observed coexpression percentages, we used standard deviation indices (SDIs) to determine how close the model's predicted coexpression percentage is to observed probability of coexpression. Similar to a Z-score, this measure is calculated as follows:

$$
\mathrm{SDI}=\left(\text { Mean }_{\text {model }}-\text { Mean }_{\text {observed }}\right) / \text { stdev }_{\text {greatest }} \text {, }
$$

where Mean $_{\text {model }}=$ mean probability of coexpression of any two given neurotransmitters from the model, e.g., mean \% TK coexpressed with MIP; Mean $_{\text {observed }}=$ mean probability of coexpression of any two given neurotransmitters from the observed coexpression relationships; and stdev $_{\text {greatest }}=$ the greatest standard deviation from either the model or observed data for a given coexpression relationship.

Weighted SDls were calculated to reflect the match between data and model for the overall population of LN by weighting the contribution of each neurotransmitter proportionally to its prevalence:

$$
\begin{gathered}
\text { Weighted SDI }=\sum\left[\left(\text { Mean }_{\text {model }}-\right.\right. \\
\text { Mean } \left.\left._{\text {observed }} / \operatorname{stdev}_{\text {greatest }}\right) *\left(n_{\text {coexpressed }} / n_{\text {total }}\right)\right] .
\end{gathered}
$$

For example, there are only 12 TK neurons in a total of 360 LNs, but 142 Mas-AT neurons. Therefore, predicting the number of Mas-AT neurons versus TK neurons should carry more weight when determining the accuracy of each model. Weighted SDIs for each coexpression relationship (i.e., weighted SDI for the TK/MIP coexpression) were summed across relationships for an overall measure of the accuracy with which each model iteration replicated observed coexpression patterns.

SDI values can be interpreted by the following scale: 0 , perfect consensus between model and experimental data; 1 , model results are within one standard deviation of experimental data and thus replicate the data reasonably well; and 2, model results are within two standard deviation of experimental data and thus do not replicate the data accurately. To determine the percent improvement of each model at replicating observed coexpression (Fig. $3 G$ ), all weighted SDIs were normalized with respect to the weighted SDI of the independent expression model using the following formula:

$\%$ improvement from independent expression model = $\left[1-\left(\right.\right.$ weighted $\mathrm{SDI}_{x} /$ weighted $\left.\left.\mathrm{SDI}_{\text {ind }}\right)\right] * 100$.

All statistics were performed in GraphPad prism ( $v$. 5.01).

\section{Results}

The AL of Manduca is surrounded by 3 cell clusters that house the cell bodies of projection neurons and LNs. The lateral cell cluster consists of $\sim 950$ cell bodies, including 590 projection neurons and $\sim 360$ total LNs (Homberg et al., 1988), of which $\sim 170$ are GABAergic (Hoskins et al., 1986). Manduca LNs are diverse across several traits, with no correlations between physiologic properties, morphologic properties, or GABA expression patterns in LNs (Reisenman et al., 2011). We therefore took a systematic approach to determine if transmitter coexpression could reliably subcategorize and explain the apparent heterogeneity of LN cellular properties.

\section{Neuropeptide coexpression is highly heterogeneous}

We first determined the pairwise coexpression relationships for GABA and multiple neuropeptides TK, FMRF, 

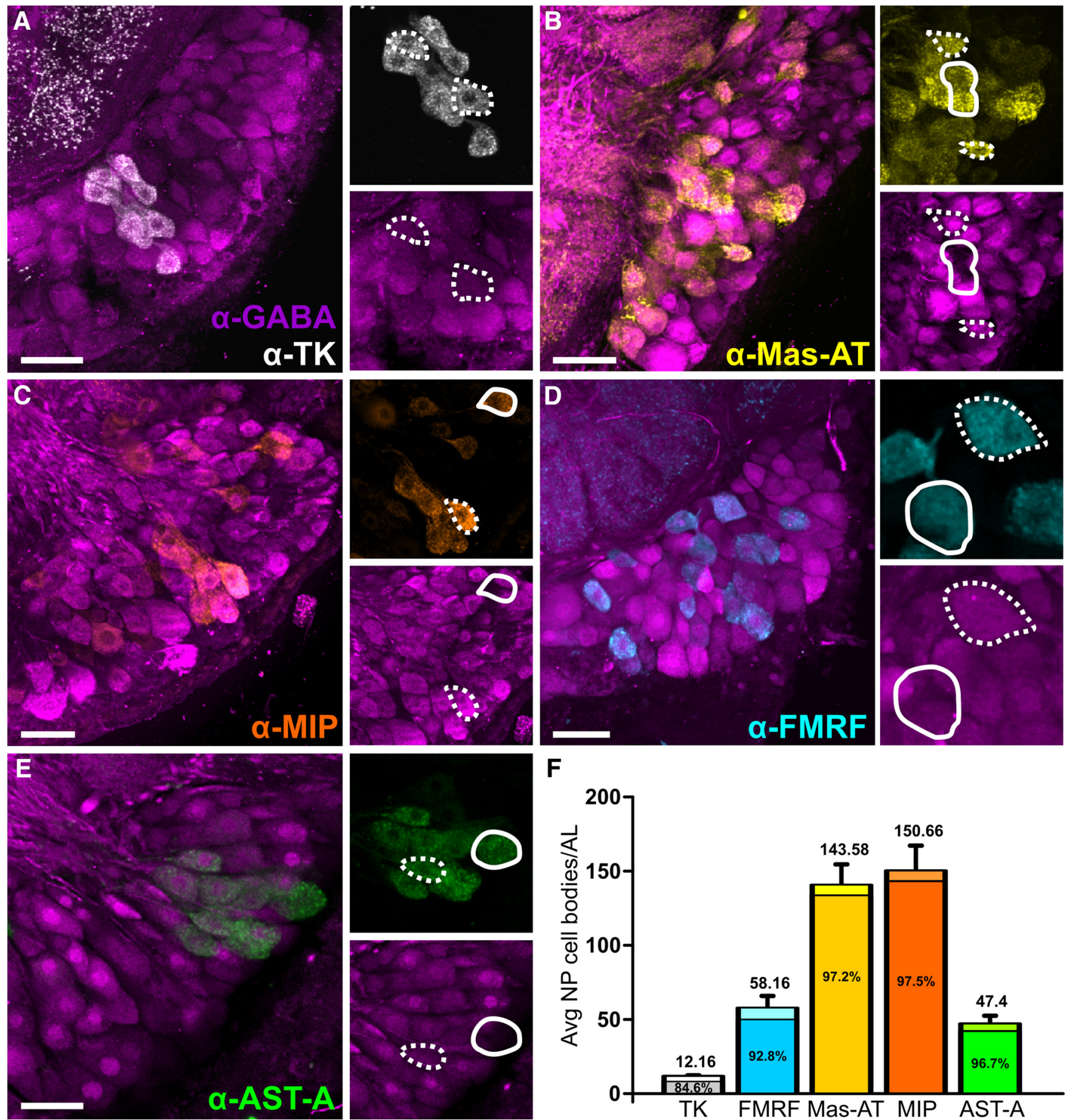

$\mathbf{F}$
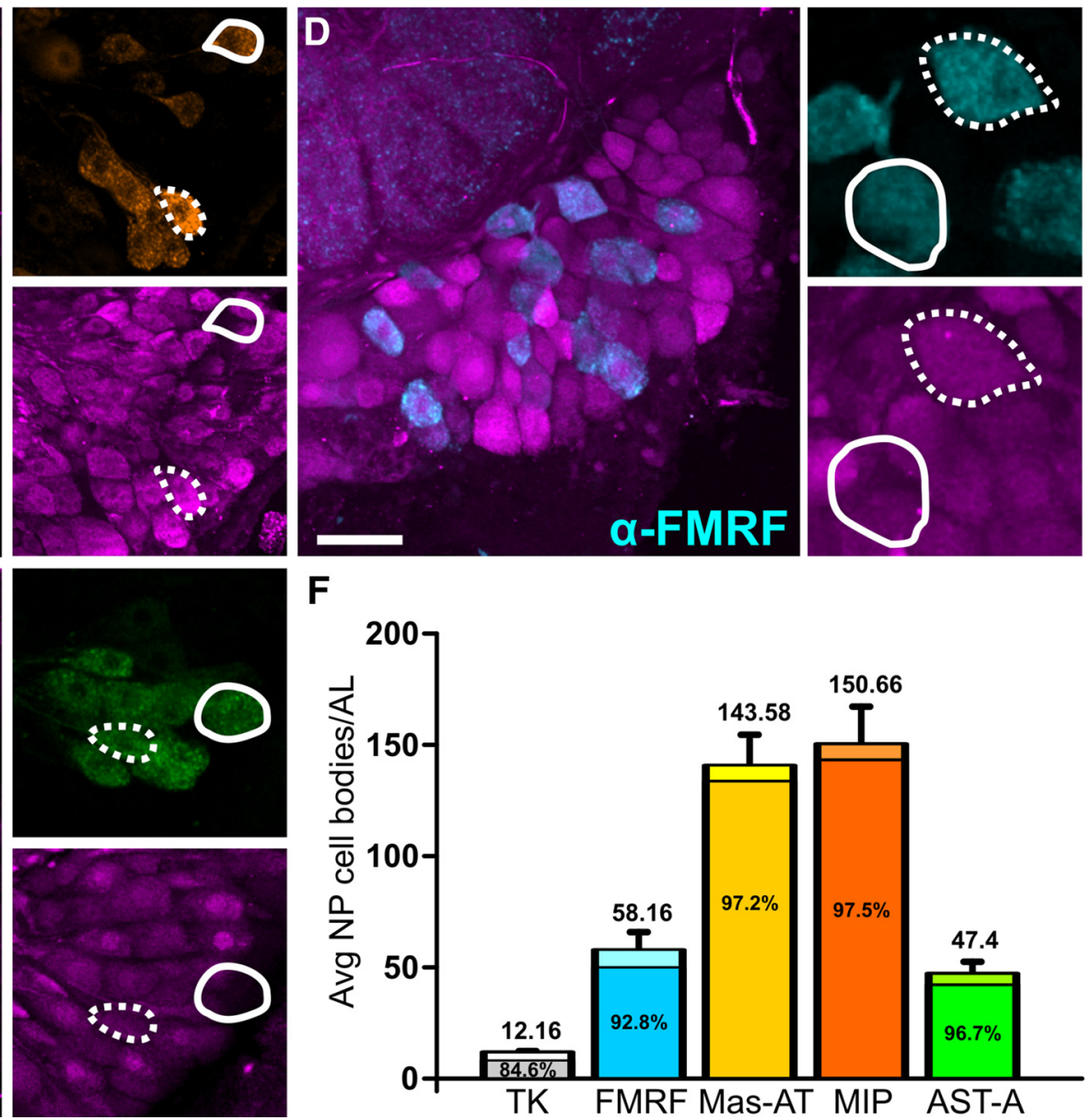

Figure 1. Peptidergic LNs predominantly coexpress GABA. Dashed lines, coexpressed; solid lines, not coexpressed. $\boldsymbol{A}$, Lateral cell cluster (LCC) labeled for GABA (magenta) and TK (white). B, LCC labeled for GABA (magenta) and Mas-AT (yellow). C, LCC labeled for GABA (magenta) and MIP (orange). D, LCC labeled for GABA (magenta) and FMRFamide (cyan). E, LCC labeled for GABA (magenta) and AST-A (green). $\boldsymbol{F}$, Bar graph of average number of cell bodies (above bars) that express each transmitter type per AL and the percentage (within bars) of each neuropeptide population per AL that coexpress GABA. See Table 2 for averages and standard deviations. $n=6$ animals per combination. All scale bars $=50 \mu \mathrm{m}$.

Mas-AT, MIP, and AST-A in LNs (Fig. 1A-E). We chose these neuropeptides because there are available antibodies of sufficient quality, we have performed the proper pre-adsorption controls for each of them, and finally these neuropeptides have the best functional, biochemical, and developmental characterization in Manduca as well as other insect species (Carroll et al., 1986; Blackburn et al., 2001; Skaer et al., 2002; Teal, 2002; Utz and Schachtner, 2005; Utz et al., 2007; Yapici et al., 2008; Ignell et al., 2009; Asahina et al., 2014; Ko et al., 2015). All moths were naïve and unmated adults, and equal numbers of males and females were used for each transmitter combination. 

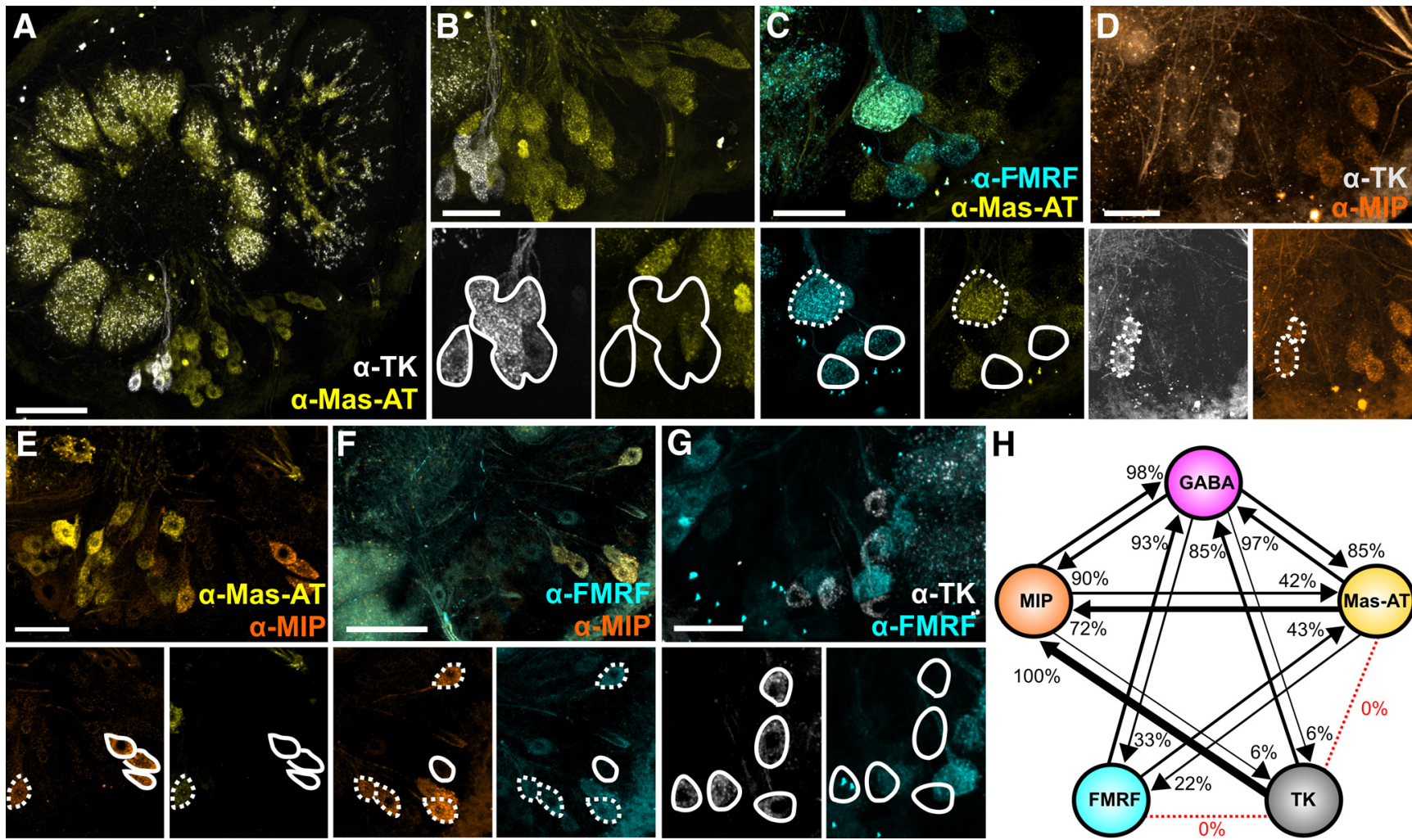

Figure 2. Neuropeptide coexpression is heterogeneous. Dashed lines, coexpressed; solid lines, not coexpressed. Coexpression for $\boldsymbol{A}, \boldsymbol{B}$ : TK (white) and Mas-AT (yellow), $\boldsymbol{C}$ : FMRFamide (cyan) and Mas-AT, $\boldsymbol{D}$ : TK and MIP (orange), $\boldsymbol{E}$ : Mas-AT and MIP, $\boldsymbol{F}$ : FMRFamide and MIP, and G: TK and FMRFamide. All scale bars $=50 \mu \mathrm{m}$. $\boldsymbol{H}$, Schematic representation of transmitter coexpression by LNs. Each circle represents the population of LNs that express a given transmitter. Arrow width and percentage located at arrowhead represent proportion of a given LN type (arrow origin) that also express a second transmitter (arrow destination). FMRFamide and MIP coexpression could not be calculated for technical reasons (see Methods). No TK LNs coexpressed FMRFamide or Mas-AT. Non-GABAergic LNs are not depicted.

Using a paired $t$ test, we found no significant differences between the left and right lateral cell clusters for all peptides: Mas-AT ( $t=1.718$; df $=5 ; p=0.1465)$, MIP $(t=$ $0.1056 ; \mathrm{df}=5 ; p=0.9200)$, FMRF $(t=0.5324 ; \mathrm{df}=5 ; p$ $=0.6172), \mathrm{TK}(t=1.085 ; \mathrm{df}=5 ; p=0.3276)$, AST-A ( $t=$ $0.6407 ; \mathrm{df}=5 ; p=0.5499$ ). We also compared counts from male and female moths and, using a paired $t$ test, we found no significant differences in cell counts between males and females for MIP $(t=1.531 ; \mathrm{df}=2 ; p=0.2654)$, AST-A $(t=0.4187 ; \mathrm{df}=2 ; p=0.7161)$, TK $(t=0.0000 ; \mathrm{df}$ $=2 ; p=1.0)$, FMRF $(t=0.1220 ; \mathrm{df}=2 ; p=0.9141)$. There was a significant difference between males and females in Mas-AT expression (t 11.97; df 2; $p$ 0.0069) with females exhibiting higher Mas-AT expression than males (Male avg: 133, Female avg: 180). Peptidergic LNs predominantly coexpressed GABA (Fig. $1 F$, Table 1), suggesting that $L N s$ can be broadly subdivided into GABAergic/peptidergic and non-GABAergic/non-peptidergic LNs. The non-GABAergic LNs have the potential to be glutamatergic, as RT-qPCR on lateral cell cluster mRNA revealed that the vesicular glutamate transporter (vGLUT) was highly expressed relative to a reference gene (40s ribosomal protein s3; RpS3, see Table 3 for Cq values). A large population of glutamatergic LNs in Manduca, in addition to the GABAergic LNs, would be consistent with the organization of the Drosophila AL (Das et al., 2011; Liu and Wilson, 2013). We then determined the coexpression ratios (i.e., what percentage of $X$-expressing neurons coexpress $\mathrm{Y}$ ) of every pairwise combination of TK, FMRF, Mas-AT, and MIP (Fig. 2A-G). There were few consistent coexpression patterns, suggesting that most LNs coexpress multiple neuropeptides to a variable degree (Fig. $2 E, G, C)$. The exception to this rule was TK, which was coexpressed $100 \%$ with MIP and never coexpressed with FMRF and Mas-AT (Fig. 2A,B,D,H). The 12 TKergic LNs were therefore the only LNs that expressed a consistent transmitter profile. Our results are consistent with other studies of GABA and peptide expression in Manduca (Hoskins et al., 1986; Homberg et al., 1990; Utz et al., 2008). Coexpression ratios for each pairwise coexpression relationship (i.e., percentage of neurons that coexpress $X$ and $Y$ ) revealed that apart from TK, neuropeptides were coexpressed to a variable degree (Fig. $2 H$ ).

\section{Computational analysis of transmitter coexpression reveals that independent expression probability} cannot explain observed transmitter coexpression in LNs

Two possible scenarios can explain the lack of apparent systematic association between specific neuropeptides coexpressed by LNs. In one scenario, expression of a given neuropeptide is independent of the expression of 
A

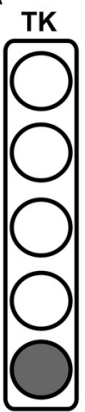

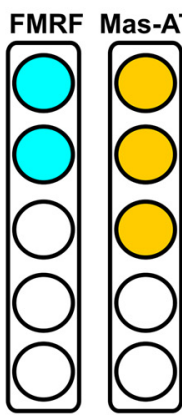
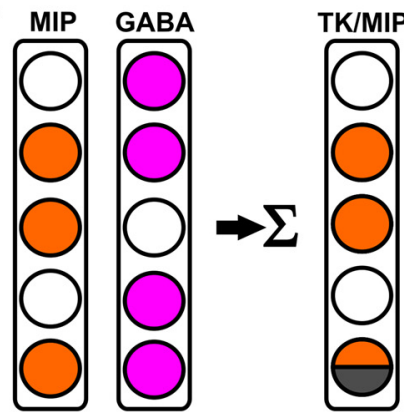

B

Independent expression
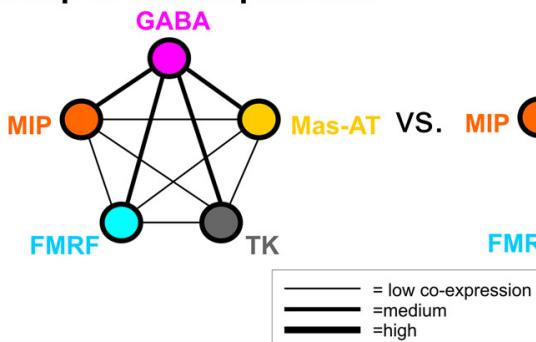

observed

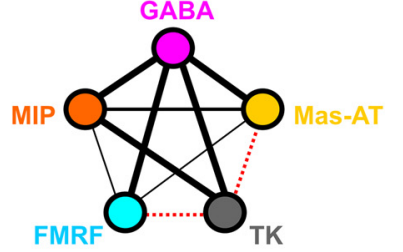

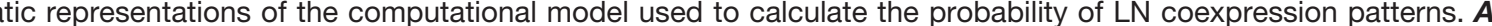
Each column represents a transmitter, and the number of rows corresponds to the total number of neurons in the population (reduced in this illustration to 5 total cells for the sake of simplicity, 360 LNs in reality). The number of neurons in each column that are transmitter positive correspond to the average number of neurons (standard deviations built in) that express each transmitter that we observed using immunocytochemistry (see Fig. $1 F$ and Table 1 for values). The model then sums across each row in a pairwise fashion to determine the coexpression percentage of a given transmitter pair. For example, for TK/MIP, the model would predict that $1 / 3$ or $33 \%$ of MIP neurons (orange) would coexpress TK assuming independent probabilities of expression for each transmitter. $\boldsymbol{B}$, Schematic representation comparing predicted coexpression percentages from the independent expression model to our observed coexpression patterns. Each circle represents a population of LNs that express a given transmitter. Given the number of neurons that express each individual transmitter (values in Fig. $1 F$ and Table 1), the model calculates the probability that a neuron will coexpress two transmitters. Line thickness represents degree to which transmitters are coexpressed. We then compare the predicted coexpression from our independent expression model to our observed coexpression values to see if observed coexpression can be explained based on independent probability of expression.

another, and the likelihood of specific coexpression patterns is equal to the independent probabilities of expression of each transmitter given the number of LNs that express each transmitter. Alternatively, specific pairs of neuropeptides are coexpressed more (or less) often than by chance, and a certain number of such relationships can explain the overall pattern of neuropeptide coexpression. To test these scenarios, we began by using computational modeling to test the hypothesis that coexpression could be explained independent probabilities of expression of each transmitter alone. Given the known total number of LNs in the lateral cell cluster (360; Homberg et al., 1988) and the total number of LNs expressing each neuropeptide (Fig. 1), the model calculates the probability of a neuron coexpressing two transmitters (Fig. 3A; see Methods). The model predicts the percentage of neurons that coexpress every pairwise relationship of transmitters in our study. For example, based on the number of LNs that express Mas-AT and the number of LNs that express FMRFamide, and the total number of $L N s$ in the $A L$, the model determines that $12 \%$ of Mas-AT neurons should coexpress FMRF if the probability of expressing the former is independent of the probability of expressing the latter. However, based on our immunocytochemical data, we observed that $22 \%$ of Mas-AT neurons coexpress FMRF (Fig 2H). We then compared every predicted coexpression ratio from the model (which assumes independent probabilities of expression of each transmitter for each pairwise relationship) to the observed coexpression ratios (Fig. $2 H$ ) and determined how well the model replicates observed coexpression (Fig. 3B). If coexpression probabilities can be replicated by a model that assumes independent expression of each transmitter, then as a result, no organizing coexpression dependencies will be identified.
We found that most coexpression relationships were not replicated by a model assuming independent transmitter expression (Fig. 4A; independent expression model). To statistically measure how well our model replicated observed coexpression patterns, we then used an SDI for every predicted pairwise coexpression relationship versus observed coexpression. An SDI score of 0 indicates that our simulation perfectly recapitulates observed coexpression patterns, whereas an SDI score $>1$ indicates poor performance of the model. Each predicted coexpression ratio from the model was compared to the observed coexpression ratios, and a SDI was calculated $\left[S D I=\left(\right.\right.$ Mean $_{\text {model }}-$ Mean $\left._{\text {observed }}\right) /$ stdev $\left._{\text {greatest }}\right]$. SDI scores for every pairwise coexpression relationship were statistically weighted (see Methods), such that coexpression relationships that included a larger proportion of the total LN population carried more weight. SDI scores revealed that while an independent-expression model could replicate some coexpression relationships (with a weighted SDI of 1.49), independent expression alone does not accurately replicate the observed coexpression (Fig. 4B).

\section{A few specific coexpression constraints allow replication of overall coexpression patterns}

Since the independent expression of each transmitter did not replicate the overall probabilities of coexpression patterns, we next sought to identify which coexpression relationship must be adjusted to replicate the overall structure of coexpression. We implemented, in our model, rules according to which the probability of expression of a transmitter is dependent on the expression of another transmitter (Fig $5 A$ ), thereby explicitly setting the probability of coexpression to its observed value (Fig. 2H). Therefore, the model contains a set number of coexpres- 
A

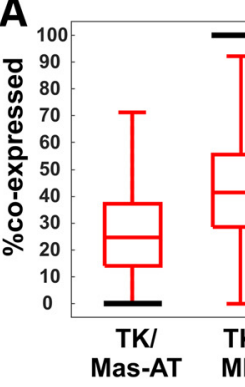

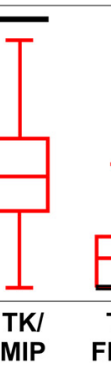

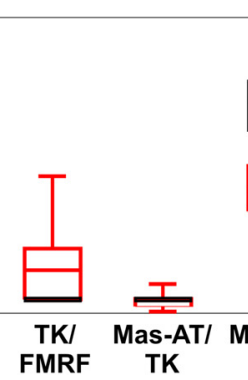

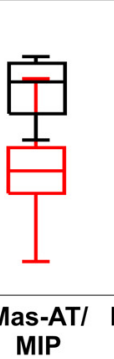

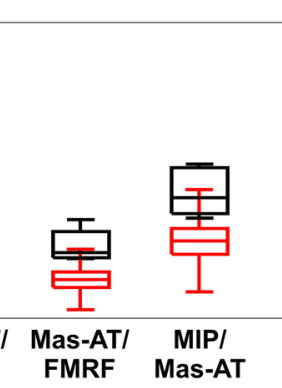

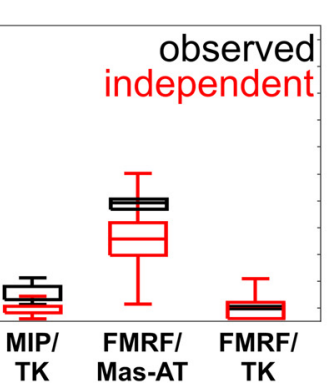

B Independent expression sD

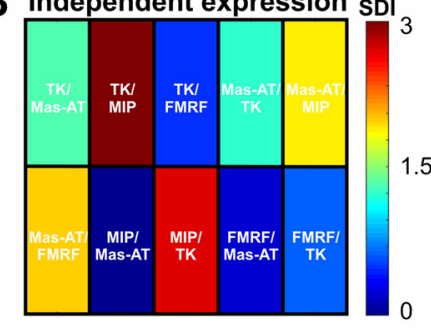

Figure 4. Computational analysis of transmitter coexpression reveals that independent expression probability cannot explain observed transmitter coexpression in LNs. A, Predicted coexpression percentages for every pairwise relationship from the independent coexpression model (red) versus observed coexpression percentages (black). A model that assumes independent probability of coexpression could not replicate observed coexpression percentages. B, Statistical comparison of the independent coexpression model's prediction versus observed coexpression reveals that independent probability of coexpression alone cannot replicate observed LN coexpression patterns. Each colored rectangle represents an individual pairwise relationship (e.g., TK/Mas-AT). SDIs were calculated for every pairwise relationship to determine how closely the model could replicate observed coexpression. An SDI of 0 (blue) denotes no statistical difference between observed coexpression and predicted coexpression from the model, thus representing coexpression relationships that the model was able to replicate very well. SDI values $>1$ indicate a poor match between the model and observed values.

sion relationships in the form of rules (for example, $42 \%$ of MIPergic LNs coexpress Mas-AT as observed from our immunocytochemistry), while leaving the rest of the relationships to emerge through probabilistically independent expression. We tested 94 different model iterations, each containing different combinations of coexpression rules to determine which combinations of rules best replicated overall observed coexpression (Fig. 5B). This allowed us to identify predictive coexpression relationships in an unbiased manner. As expected, the ability of the model to replicate observed coexpression patterns improved as more rules were added, as shown by weighted SDls from all model iterations (Fig. 5B-D).

However, some combinations of rules outperformed others. We first constrained the total number of cells in the model to the total number of GABAergic LNs $(\sim 170$ cells instead of 360 total LNs), as the presence of GABA is a reliable predictor of peptide expression observed in this study. This constraint outperformed the independentexpression model, had a weighted SDI of 0.94 , and accurately replicated more coexpression patterns (Fig. 6A). This suggests that much of the diversity of neuropeptide coexpression can be constrained to the subpopulation of GABAergic LNs in our study. All remaining model iterations were constrained to the total number of GABAergic LNs [Fig. 5B; filled-in symbols indicate models where total number of $L N s=170$ (with stdev) GABAergic neurons]. Unexpectedly, one particular model that contained only 1 coexpression rule outperformed most models that were constrained by 2 and 3 rules (red square, Fig. $5 B$ ). When the proportion of MIPergic LNs expressing Mas-AT is set to its observed value $(42 \%)$, the model replicated the highest number of coexpression relationships of all models with 1 rule (Fig. $6 B-D$ ), yielded the lowest weighted SDI (0.36), and outperformed the average of models with 1 rule (lower $95 \% \mathrm{Cl}$ of mean: 0.6551 , upper $95 \% \mathrm{Cl}$ of mean: 0.9862), 2 rules (lower 95\% Cl of mean: 0.5450, upper $95 \% \mathrm{Cl}$ of mean: 0.7240 ), and even 3 rules (lower $95 \% \mathrm{Cl}$ of mean: 0.4736 , upper $95 \% \mathrm{Cl}$ of mean: 0.5897 ).
This was surprising, because it suggested that replicating observed coexpression patterns did not require all coexpression relationships to be fixed, revealing specific proportional relationships that may be may be predictive of overall observed coexpression patterns.

The only set of coexpression patterns that could not be replicated reasonably well in the model that included the GABA and the MIP/Mas-AT rules (as described above) involves TK. The 12 TK LNs (Lizbinski et al., 2016) follow a strict all-or-none neuropeptide coexpression pattern (100\% coexpression with MIP and 0\% coexpression with Mas-AT or FMRF). Consistent with our data, TK LNs in the $\mathrm{AL}$ of the moth Heliothis virescens also do not coexpress FMRF or Mas-AT (Berg et al., 2007). This coexpression pattern cannot be replicated through independent expression models, even when several other rules are considered (Fig. 6E). These coexpression patterns are so clear-cut that they set TK apart from other transmitters observed in this study.

\section{GABA $_{B}$ and neuropeptide receptors are expressed across all principal neuron types of the $A L$}

It may be unnecessary to tightly regulate coexpression of neuropeptides in specific subpopulations of LNs simply because specific classes of AL neurons express different sets of neuropeptide receptors. Thus, the heterogeneous transmitter profiles of individual LNs may not matter functionally, because the impact of individual peptides within a modulatory cocktail of many peptides may be segregated due to neuron class-specific expression of each receptor. For instance, if ORNs express the MIP receptor and PNs express the Mas-AT receptor, the influence of these two neuropeptides could differentially target input and output of the network, rather target the same neuron, resulting in different consequences on the network. However, this does not appear to be the case in this network, as we did not find differential expression of the receptors for the peptides examined in this study between ORNs, LNs, and PNs. We first identified transcripts from the 
A

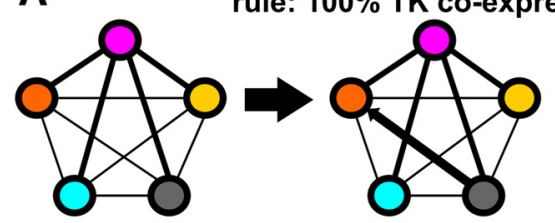

independent rule: $100 \%$ TK co-express MIP

vs.

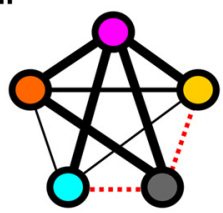

observed
B

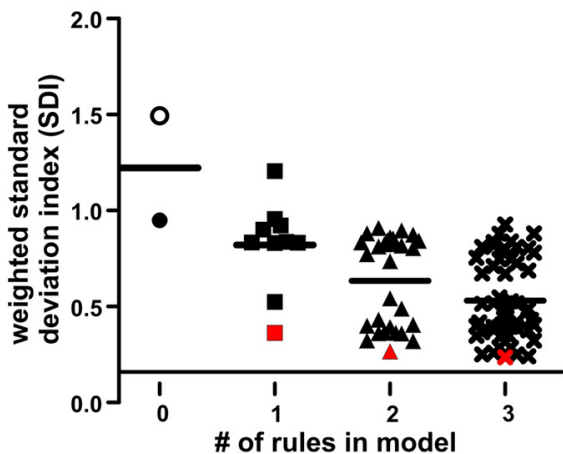

C

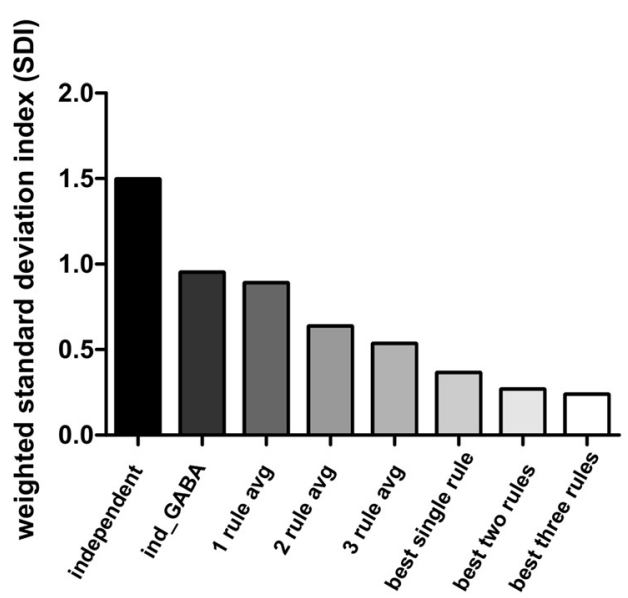

D

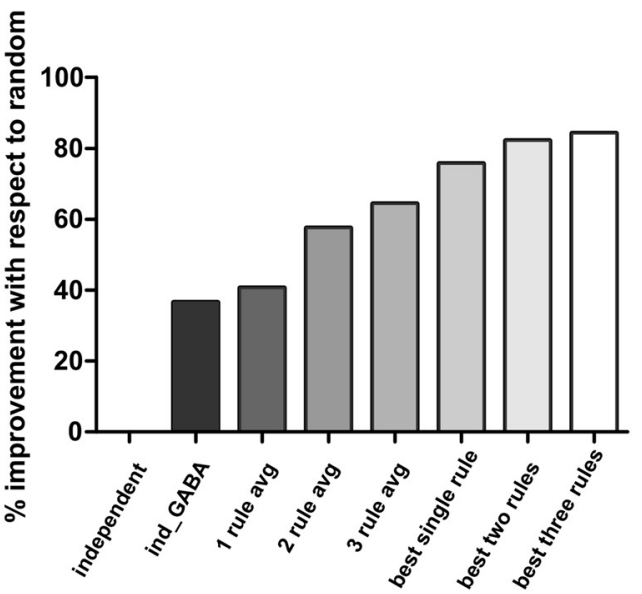

Figure 5. A few specific coexpression constraints allow replication of overall coexpression patterns. $\boldsymbol{A}$, Model constraints are applied to explicitly set the probability of a coexpression relationship to its observed value. In this example, a constraint is set in which $100 \%$ of TK LNs coexpress MIP, while leaving the remaining relationships to emerge through probabilistically independent expression. This model is then compared to observed coexpression data. $\boldsymbol{B}$, Specific rules outperform others at replicating observed coexpression patterns. Open circle represents model run with total number of LNs set to 360 . Closed symbols represent models runs with total number of neurons set to the total number of GABAergic LNs $(\sim 170)$. Red denotes standout iterations of the model that best replicated observed coexpression. The single rule that shifted the prediction closest to observed coexpression was when the proportional relationship between MIP/Mas-AT was set as a static rule in the model (red square). The two rules that shifted the prediction closest to observed coexpression were MIP/Mas-AT and TK/Mas-AT. The three rules that shifted the prediction closest to observed coexpression were TK/Mas-AT + Mas-AT/MIP + FMRF/Mas-AT. $\boldsymbol{C}$, Weighted SDI values for various model iterations. The model improves as more rules are added. $\boldsymbol{D}$, Percentage improvement of each model's predictive power with respect to the independent expression model. Both GABA constraint and MIP/Mas-AT rule drastically improved the model's ability to replicate coexpression patterns. Note that the MIP/Mas-AT rule model even outperformed the average prediction of all models containing three rules.

Manduca genome (Kanost et al., 2016) with high sequence identity to neuropeptide receptors identified from reference genomes in closely related species (Table 2). Then, using RT-qPCR, we determined the relative expression of five neuropeptide receptors (Mas-AT, MIP, AST-A, FMRF, TK) and the $\mathrm{GABA}_{\mathrm{B}}$ receptor in mRNA from the antennae (which house ORNs), the medial cell cluster (which houses only PNs), the lateral cell cluster (which houses LNs and PNs), and whole brains (as a positive control). Although the receptors for Mas-AT, MIP, AST-A, $F M R F$, and $G A B A_{B}$ were detected in all four tissue types, the TK receptor was not detected in the lateral cell cluster (Fig. 7; for raw qPCR data, see Table 3). This suggests that TKergic LNs differ from other LNs in both their coexpression patterns and their postsynaptic targets. Although we could not assess receptor expression on a neuron-by-neuron basis, our results suggest that a single $\mathrm{LN}$ releasing neuropeptides from at least four individual peptide families can have a powerful effect on the network, potentially affecting all three major cell classes in the AL.

\section{Discussion}

Broad neuronal classes are surprisingly heterogeneous across many parameters, and subclasses often exhibit partially overlapping traits including transmitter coexpression. Our goal was to determine organizing principles of LN heterogeneity. Our results suggest that neuropeptide coexpression in the $\mathrm{AL}$ is both heterogeneous and partially overlapping across the entire population rather than consistent within specific subpopulations of LNs (Fig. 8). Thus, peptidergic modulation cannot be considered within the context of single neuropeptides, as activation of any given LN results in a dynamic cocktail of modulators that have the potential to influence every level of olfactory processing within the AL. Specifically, we find that trans- 
A

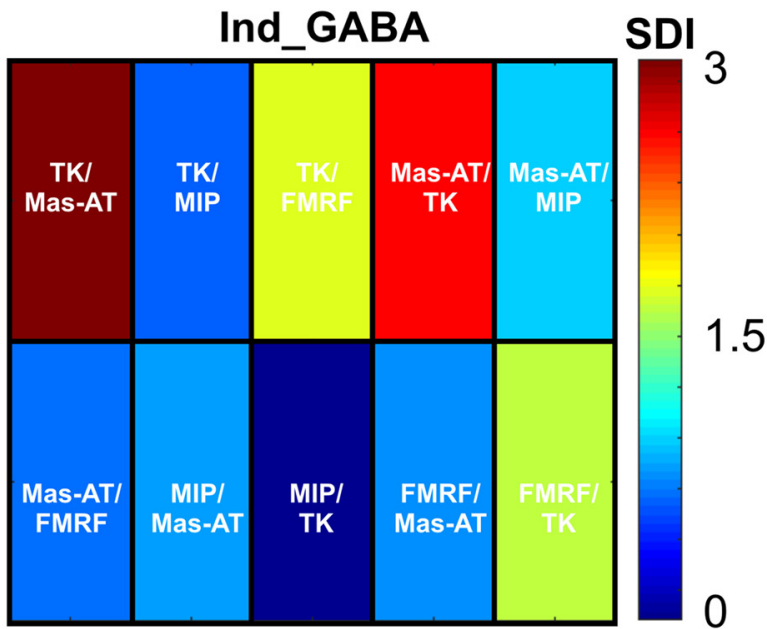

B

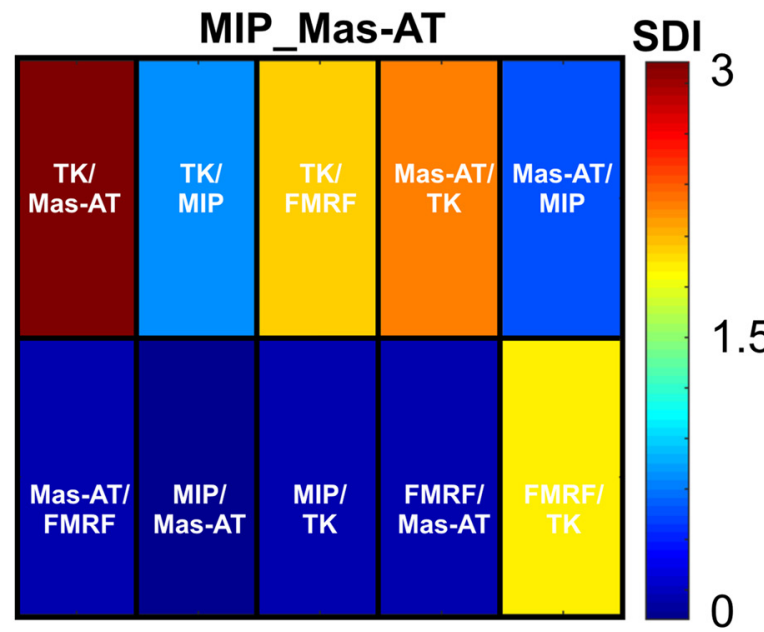

C

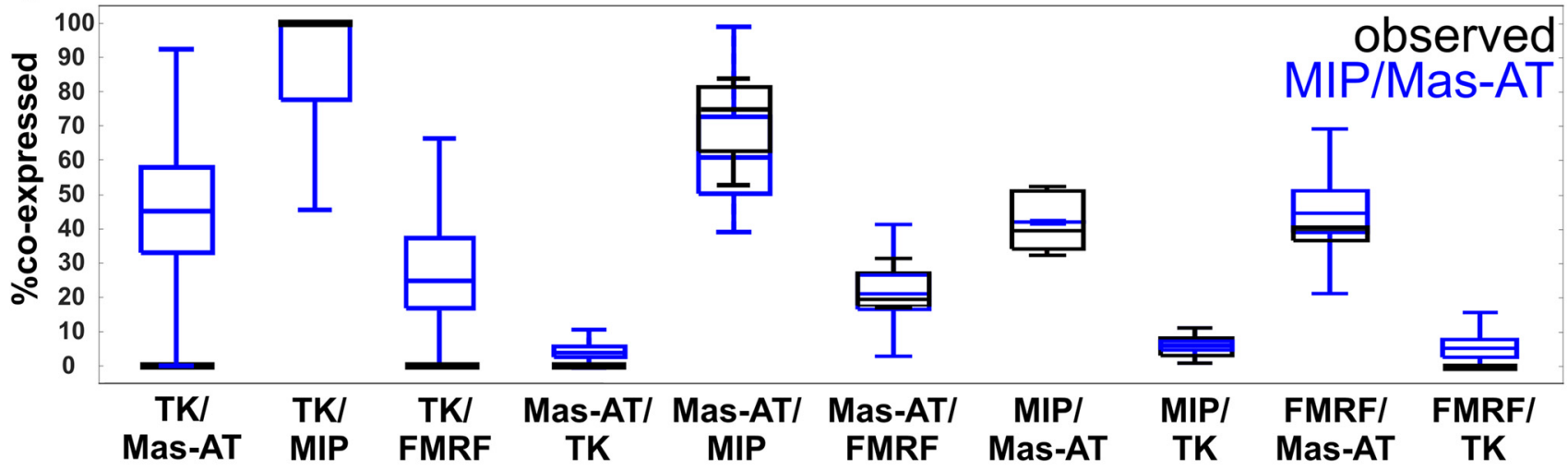

D

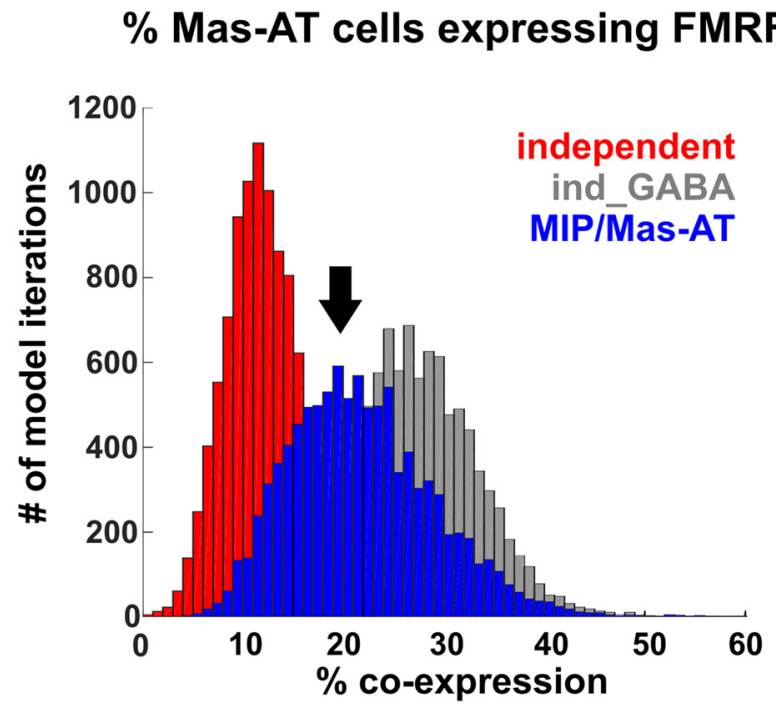

$\mathbf{E}$ \% TKK cells expressing Mas-AT

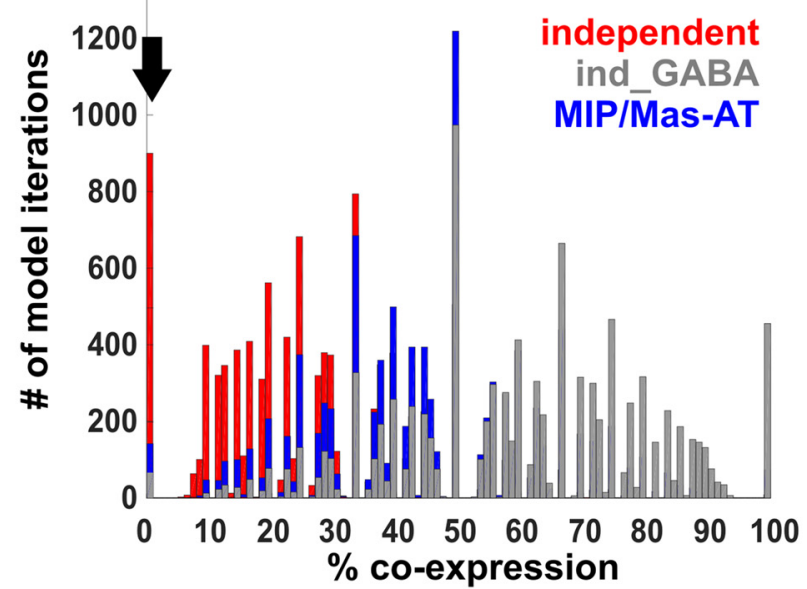

Figure 6. MIP/Mas-AT coexpression rule best biases the model to replicate observed coexpression patterns. $\boldsymbol{A}$, Reducing the total number of neurons in the model to the total number of GABAergic LNs (170) improves model performance. SDI $=0$ (blue) denotes no statistical difference between observed coexpression and predicted coexpression. SDI $>1$ indicates a poor match between the model and observed values. $\boldsymbol{B}$, Constraining the model based on MIP/Mas-AT coexpression causes the model to reliably replicate many observed coexpression patterns. A model following this single rule outperformed the average of all models containing three set coexpression rules. $\boldsymbol{C}$, All predicted pairwise coexpression percentages from the model following the MIP/Mas-AT rule (blue) versus observed coexpression percentages (black). $\boldsymbol{D}$, Neither independent (red), nor ind_GABA (gray) models reliably replicated observed coexpression patterns (Mas-AT/FMRF used as an example). However, the MIP/Mas-AT (blue) constraint best replicates observed coexpression patterns (denoted by black arrow). E, Observed TK coexpression patterns (TK/Mas-AT used an example) were not 
continued

reliably replicated by any model iteration; independent expression model prediction (red), ind_GABA model (gray), and MIP/Mas-AT model prediction (blue).

mitter profile is heterogeneous across LNs, with individual olfactory LNs capable of expressing the main inhibitory transmitter GABA and peptides from at least four families, and few instances in which transmitters are consistently coexpressed. Observed coexpression patterns cannot be explained by independent probabilities of expression of each transmitter (Fig. 4). Our analyses point to three organizing principles that, once taken into consideration, allow replication of overall coexpression structure: (1) peptidergic neurons are highly likely to coexpress GABA; (2) the probability of expressing Mas-AT is dependent on MIP expression; and (3) the all-or-none coexpression patterns of TKergic neurons with several other neuropeptides (MIP, FMRF, and Mas-AT). For other pairs, the presence of one transmitter was not predictive of the presence of the other, and thus coexpression probability could be replicated by independent probabilities. The stochastic nature of these coexpression patterns argues against clear-cut, exclusive definition of subpopulations based on the presence of single neuropeptides. Furthermore, the receptors for GABA and all neuropeptides in this study were expressed within each population of principal neuron type in the $A L$ (Fig. 7), suggesting that peptides released from LNs potentially influence every level of olfactory processing within the AL. Overall, we demonstrate that peptide expression is partially overlapping across LNs, and thus subpopulations of LNs cannot be functionally defined based on the presence of single peptides. Furthermore, the influence of peptides are not segregated based on cell class-specific receptor expression.

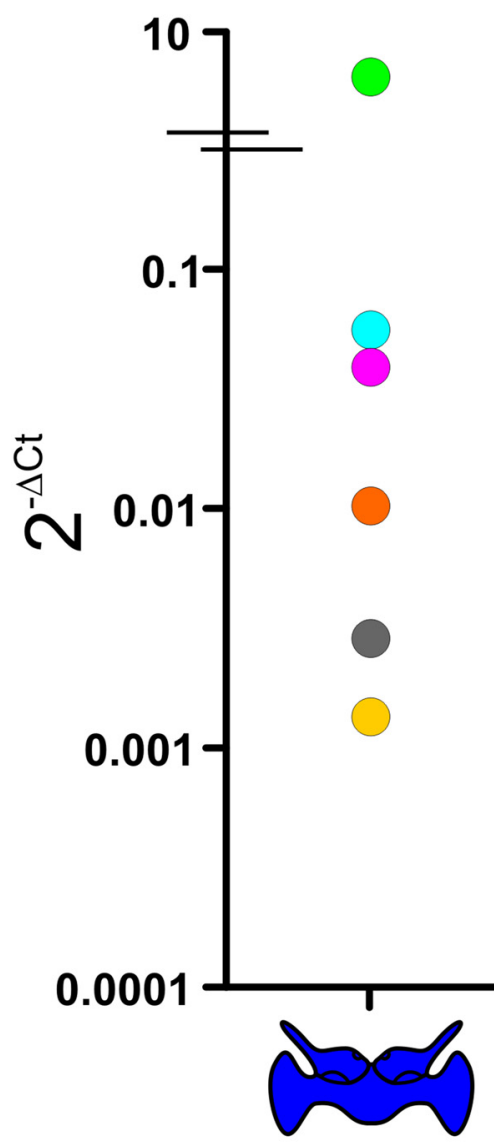

brain

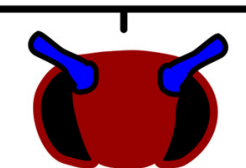

antennae

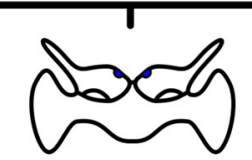

MCC
$\mathrm{TKr}$

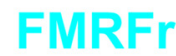

Mas=ATr

MIPr

AST-Ar

GABA $_{B} r$

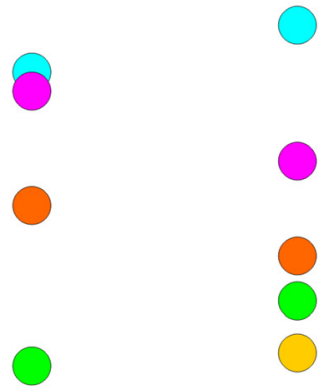

N.D.

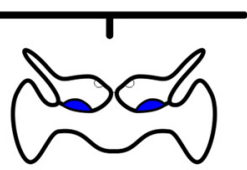

LCC

Figure 7. Neuropeptide and $\mathrm{GABA}_{\mathrm{B}}$ receptor expression across principal neuron types of the AL. Relative receptor expression for Mas-ATr, MIPr, ASTr, FMRFr, GABA ${ }_{B} r$ are present in all tissue types and therefore expressed in ORNs, LNs, and PNs in varying expression levels. Cartoons on the $x$-axis represent the tissue type (blue) used to extract mRNA from each population of principal olfactory cell types. TK was not detectable (N.D.) in lateral cell cluster mRNA and therefore not detectable in LNs. RpS3 was used as the reference gene. See Table 2 for primer sequences and Table 3 for raw Cq values for all receptors. 


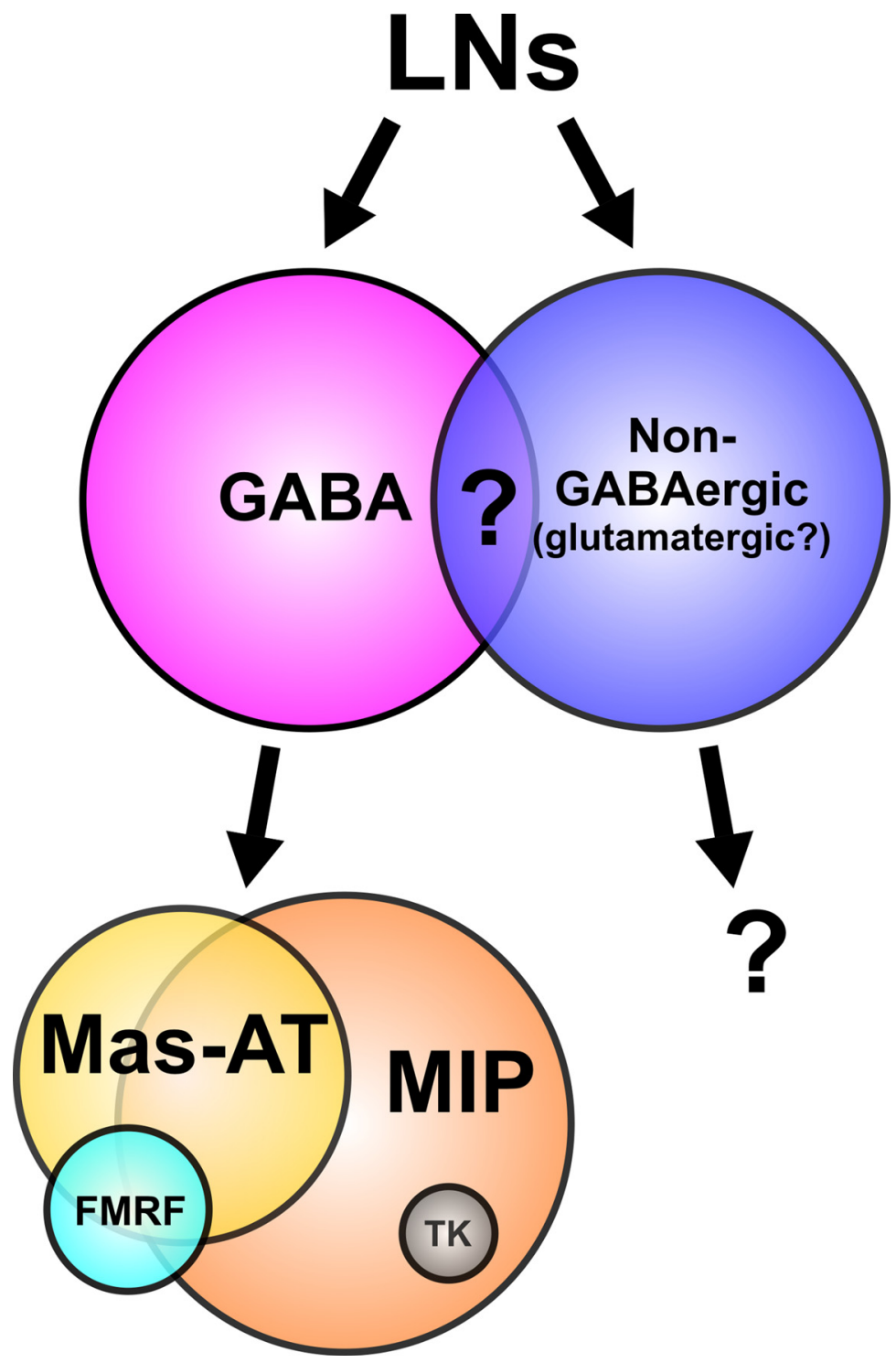

Figure 8. Heterogeneous transmitter coexpression in LNs blurs subdivisions. While LNs can be broadly subdivided based on small transmitter [GABA versus non-GABAergic (glutamatergic?)], coexpression within the GABAergic class reveals that LNs subclasses cannot be identified on individual transmitter expression alone. Neuropeptide coexpression in the AL is both heterogeneous and partially overlapping across the entire population rather than consistent within specific subpopulations of LNs.

Thus, co-release of peptides and GABA likely mediates a complex mix modulation to control the dynamic range of the AL, providing multiple mechanisms to alter olfactory processing.

Heterogeneous transmitter coexpression is a common theme within GABAergic LNs across vertebrates and invertebrates alike (Homberg et al., 1990; Maccaferri and Lacaille, 2003; Flames and Marín, 2005; Utz et al., 2008; Carlsson et al., 2010; DeFelipe et al., 2013; Siju et al., 2014; Binzer et al., 2014; Gabitto et al., 2016; Yavorska and Wehr, 2016; Diesner et al., 2018a). MALDI-TOF spectrometry revealed that at least 12 known peptides are expressed in developing Manduca ALs (Utz et al., 2007), suggesting that coexpression patterns are likely even more complex than detailed here. Furthermore, the antibodies used in this study recognize multiple isoforms of peptides within the same family (i.e., FMRF has multiple isoforms), and thus there are almost certainly more organizational principals underlying heterogeneous peptide expression than discussed here. Other insects including mosquitos (Siju et al., 2014), other species of moths (Berg et al., 2007; Diesner et al., 2018a), beetles (Binzer et al., 2014), and fruit flies (Carlsson et al., 2010; Hussain et al., 2016; Croset et al., 2018) express a large number of peptides within their olfactory systems, suggesting that peptides likely play an important yet functionally underexplored role in shaping olfactory responses. One exception to the theme of heterogeneous coexpression was that the TK neurons differed in their patterns of coexpression from other peptidergic LNs. All TK LNs coexpressed MIP, and none coexpressed FMRF or Mas-AT, suggesting that TK LNs are primarily inhibitory, as TK and MIP receptors are inhibitory in Drosophila (Yapici et al., 2008; Ignell et al., 2009; Ko et al., 2015). Furthermore, TK receptor tran- 
scripts were not detected in lateral cell cluster mRNA and thus not in LNs, although TK/MIPergic LNs could still influence $L N s$ via $\mathrm{GABA}_{\mathrm{B}}$ and MIP receptor. In Drosophila melanogaster, TK mediates presynaptic gain control on ORNs (Ignell et al., 2009), and TKr expression in Manduca ORNs is consistent with this finding. This suggests that TK LNs may play a role distinct from other LNs in olfactory processing, which could include presynaptic gain control.

Very few non-GABAergic LNs coexpress the neuropeptides we examined here; however, they are still a sizeable proportion of the total number of LNs and likely as heterogeneous as GABAergic LNs. We did not definitively identify the transmitter released by these LNs; however, we did detect the expression of vGlut mRNA within the lateral cell cluster (Fig. 7), making glutamate a candidate transmitter for the non-GABAergic LNs. Similar to GABAergic LNs, glutamatergic LNs in Drosophila are particularly diverse in their morphology (Das et al., 2011) but appear to differ from GABAergic LNs in their synaptic targets by predominantly affecting PNs (Liu and Wilson, 2013), while GABAergic LNs in Drosophila affect ORNs, LNs, and PNs (Wilson and Laurent, 2005; Olsen and Wilson, 2008; Root et al., 2008; Hong and Wilson, 2015). Future studies should confirm whether the non-GABAergic population observed here are truly glutamatergic.

The probability of expression of certain transmitters appears to be dependent on one another. In particular, we showed that the probability of expressing Mas-AT is dependent on the expression of MIP (Fig. 6). While the goal of our study is not to determine the developmental mechanisms that underlie coexpression, it is important to note that developmental mechanisms of peptidergic regulation most certainly shape observed heterogeneous coexpression. For instance, the molting hormone 20-hydroxyecdysone induces Mas-AT expression in LNs and other neuropeptides in the AL of Manduca (Utz and Schachtner, 2005; Utz et al., 2007), implying that coexpression patterns may reflect extrinsic developmental cues that guide the development of specific peptide-expressing LNs. Furthermore, both MasAT- and MIP-expressing LNs arise slightly before and during the formation of glomeruli, suggesting that temporal expression patterns of these peptides may play a role in the development of AL structure and function (Utz et al., 2007). Interestingly, the model constraint best able to replicate observed coexpression across all LNs in our study was the proportional relationship between MIP/Mas-AT-expressing neurons.

However, the developmental mechanisms that control peptide expression in LNs of Manduca are unknown. In Drosophila, the transcription factor DIMMED targets many genes involved in peptide expression (Hewes et al., 2003, 2006; Gauthier and Hewes, 2006; Park et al., 2008b; Park and Taghert, 2009; Hadzic et al., 2015) and dense core vesicle production (Hamanaka et al., 2010; Park et al., 2014). DIMMED likely acts in a combinatorial manner with other cell-specific transcription factors to determine peptide expression in individual neurons (Liu et al., 2016; Stratmann and Thor, 2017). Although DIMMED does not target any single neuropeptide gene (Hadzic et al., 2015), other transcription factors do regulate subtype-specific neuropeptide expression (Allan et al., 2003; Berndt et al., 2015). While DIMMED-positive neurons coexpress multiple peptides, not all peptidergic neurons express DIMMED (Park et al., 2008a; Diesner et al., 2018b), and the role of DIMMED in Manduca has not been established. Regardless, a similar combinatorial transcriptional code could underlie the heterogeneity of peptide expression observed here. Furthermore, in cortex, LN subtypes arise from unique progenitors (Anderson et al., 1997; Wichterle et al., 2001; Nery et al., 2002; Kepecs and Fishell, 2014), and their diversity is shaped by additional factors (Flames and Marín, 2005) including neural activity (Patz et al., 2004; De Marco García et al., 2011), transcription factor expression (Mayer et al., 2018; Sweeney et al., 2018), and growth factors (Huang et al., 1999). Similarly, GABAergic and glutamatergic LNs in Drosophila arise from distinct neuroblasts (Das et al., 2008, 2011), and glomerular innervation patterns of $\mathrm{LNs}$ require ORN axons during development (Chou et al., 2010), suggesting that heterogeneity of LNs may be due in part to distinct origins and/or activity of other neurons in the network.

Our study reveals some expression codependencies, but also highlights the apparent stochastic nature of other coexpression patterns. There are several examples of biological systems in which features such as gene expression in E. coli clones (Elowitz et al., 2002; Raj and van Oudenaarden, 2008; Huh and Paulsson, 2011), behavior (Honegger and de Bivort, 2018), or anatomic layout (Caron et al., 2013) appear to be randomly structured or stochastic. For example, random combinations of AL PNs from different glomeruli converge and synapse on individual mushroom body Kenyon cells in Drosophila regardless of anatomy, developmental origin, or odor tuning, thus abandoning the odor-topic organization of the AL (Caron et al., 2013). Because of the stochastic heterogeneity of some transmitter coexpression patterns, our results suggest that the presence of single peptides should not be used to functionally define classes of neurons. Additionally, this stochasticity suggests that LNs may not functionally require fixed complements of transmitters.

We found that a single neuropeptide has the potential to simultaneously target every principal neuron type, as all neuropeptide receptors were expressed by populations of ORNs, LNs, and PNs. This network-wide convergence of peptidergic modulation demonstrates that individual LNs do not differentially target principal neuron type based on differences in postsynaptic receptor expression. This further supports the idea that LN activation may serve to regulate multiple processing stages within the olfactory network by simultaneously targeting AL input, output, and local processing. However, individual neurons within each principal AL neuron type may exhibit differential receptor expression, as we were not able to assess receptor expression at the level of individual neurons. Future studies should determine if neuropeptide receptor expression is as heterogeneous as neuropeptide coexpression itself, as there are likely subpopulations of neurons that exhibit differential receptor expression. This may be further complicated, as neuropeptide receptor expression can be regulated by physiological state, as observed for the role 
of hunger (Ko et al., 2015; Min et al., 2016) or mating state in Drosophila (Hussain et al., 2016). Peptide expression itself may be similarly regulated, as observed in feeding state of Aedes aegypti (Christ et al., 2017) or mating state of Agrotis ipsilon moths (Diesner et al., 2018a). All moths in our study were naïve and unmated; however, this does not rule out the potential for physiologic state to affect peptide expression in the AL.

Activation of even a single $\mathrm{LN}$ can mediate a complex mix of inhibition and/or excitation that varies in time course and strength due to the co-release of the smalltransmitter GABA and a heterogeneous mix of peptides. LNs, apart from TK LNs, coexpressed multiple peptide families and GABA that activate both inhibitory (TK, sNPF, and sex-peptide/MIP; Yapici et al., 2008; Ignell et al., 2009; Asahina et al., 2014; Ko et al., 2015) and excitatory (Mas-AT and FMRF; Horodyski et al., 2011; Lenz et al., 2015; Ormerod et al., 2015) receptors via a mix of ionotropic and metabotropic signaling. Furthermore, AL neurons express both the GABA $A_{a}$ and $\mathrm{GABA}_{\mathrm{B}}$ receptors, and the effects of $G A B A_{B}$ receptor activation are far shorterlasting relative to neuropeptide receptors (Salio et al., 2006). Thus, small-transmitter and peptide coexpression expands the temporal scale with which a single neuron can alter network processing. However, it is unclear whether LNs employ bulk and/or restricted synaptic release of peptides, making the spatial scale of their influence unknown. Finally, the network may need to be more strongly activated (i.e., by higher concentrations of odors or increased length of odor-stimuli) for LNs to release neuropeptides owing to the different calcium binding affinities of distinct synaptotagmins associated with small clear vesicles and dense-core vesicles (Saraswati et al., 2007; Li et al., 2009). Thus, the consequences of LN activation and peptidergic modulation may depend more on the degree of network activity than the identity of any singular LN that is activated. Overall, this heterogeneous cocktail of peptides likely provides the AL with flexible options to up- or down-regulate olfactory processing over a variety of time frames and spatial scales within the context of ongoing network activity.

Within the AL, combined GABAergic and peptide release from LNs could potentially play a variety of functional roles including autoinhibition, lateral excitation or inhibition, disinhibition, and even odor-specific processing. For example, lateral input from LNs scales with overall network activity as a means to control the dynamic range of the network and avoid response saturation of PNs (Olsen and Wilson, 2008; Root et al., 2008). Additionally, some glomeruli are more subject to inhibition than others simply because of differences in glomerulus-specific, non-uniform LN innervation (Wilson and Laurent, 2005; Chou et al., 2010) and ORN GABAb receptor expression (Root et al., 2008). As a result, the processing of specific odors differs in the degree of insulation from ongoing activity in the olfactory system, and specific glomeruli are therefore more (or less) insulated from presynaptic gain control mediated by both GABA (Root et al., 2008) and, potentially, neuropeptides (Ignell et al., 2009; Ko et al., 2015; Hussain et al., 2016). Spatial activation of Drosoph- ila LNs is also odor-specific and heterogeneous, with LNs responding to either single or multiple odors ( $\mathrm{Ng}$ et al., 2002). The nonuniform innervation and heterogeneous odor-evoked responses of LNs suggests that the activation of LNs is a complex combinatorial process resulting in glomerular-specific local processing. In Manduca, most GABAergic LNs are wide-field and heavily ramify all glomeruli, suggesting that the consequences of GABAergic LN activation cannot be fully segregated based on odor identity. However, a small subset of GABAergic and nonGABAergic LNs exhibit restricted glomerular arborizations, only innervating a small subsection of the $A L$ (Reisenman et al., 2011). Consequently, activation of morphologically restricted LNs may disinhibit or inhibit other LNs from neighboring glomeruli in an odor-specific manner to increase or decrease odor salience by altering the output of PNs (Hildebrand et al., 1992; Christensen et al., 1993). While no correlations between morphology (widefield vs restricted), physiology, odor-response profile, and transmitter content have been identified in Manduca LNs (Reisenman et al., 2011), it could be that wide-field versus restricted LNs exhibit distinct and predictable combinations of peptides. These potential network consequences are likely applicable across insect species, as LN heterogeneity is a recurring theme. Using physiology paired with hierarchical clustering based on morphology, multiple Drosophila LN subtypes exhibit broad correlations between morphology, physiology, and genetic classes (Chou et al., 2010). However, LNs within the "patchy" cell type exhibit highly variable innervation patterns, and considerable diversity exists even within other $L N$ subtypes (Chou et al., 2010). Additionally, morphologically and functionally distinct classes of LNs exist in honeybees (Schäfer and Bicker, 1986; Flanagan and Mercer, 1989; Fonta et al., 1993; Sun et al., 1993; Bornhauser and Meyer, 1997; Seidel and Bicker, 1997; Galizia and Kimmerle, 2004; Dacks et al., 2010) and cockroaches (Malun, 1991; Distler and Boeckh, 1997; Loesel and Homberg, 1999; Husch et al., 2009a, b; Fusca et al., 2013, 2015; Neupert et al., 2018). Ultimately, determining the roles of individual peptides will be challenging, as complex patterns of coexpression must be integrated with knowledge of functionally distinct subtypes of LNs.

Reconciling within-cell-type heterogeneity represents an ongoing challenge. Similar to LNs across taxa and brain region, Manduca LNs are highly heterogeneous across many parameters. This heterogeneity provides multiple coding strategies and mechanisms to neurons within the same population, expanding the role single neurons play in altering network function. The link between heterogeneous response properties and neural coding has been studied in a wide range of systems (Chelaru and Dragoi, 2008; Marsat and Maler, 2010; Ogawa et al., 2011; Pitkow and Meister, 2012; Ahn et al., 2014); however, the systematic analysis of heterogeneous traits such as transmitter coexpression has not been as extensively explored. Here, we show that traits such as transmitter coexpression are partially overlapping across the entire LN population. Ultimately, our results demonstrate that peptidergic modulation cannot be considered 
within the context of single neuropeptides, as activation of any given $\mathrm{LN}$ results in a dynamic cocktail of modulators that have the potential to influence every level of olfactory processing within the AL.

\section{References}

Ache BW, Young JM (2005) Olfaction: diverse species, conserved principles. Neuron 48:417-430. CrossRef Medline

Ahn J, Kreeger LJ, Lubejko ST, Butts DA, MacLeod KM (2014) Heterogeneity of intrinsic biophysical properties among cochlear nucleus neurons improves the population coding of temporal information. J Neurophysiol 111:2320-2331. CrossRef Medline

Allan DW, St Pierre SE, Miguel-Aliaga I, Thor S (2003) Specification of neuropeptide cell identity by the integration of retrograde BMP signaling and a combinatorial transcription factor code. Cell 113: 73-86. CrossRef

Anderson SA, Eisenstat DD, Shi L, Rubenstein JL (1997) Interneuron migration from basal forebrain to neocortex: dependence on Dlx genes. Science 278:474-476. Medline

Asahina K, Watanabe K, Duistermars BJ, Hoopfer E, González CR, Eyjólfsdóttir EA, Perona P, Anderson DJ (2014) Tachykininexpressing neurons control male-specific aggressive arousal in Drosophila. Cell 156:221-235. CrossRef Medline

Bell RA, Joachim FG (1976) Techniques for rearing laboratory colonies of tobacco hornworms and pink bollworms LepidopteraSphingidae-Gelechiidae. Ann Entomol Soc Am 69:365-373. CrossRef

Berg BG, Schachtner J, Utz S, Homberg U (2007) Distribution of neuropeptides in the primary olfactory center of the heliothine moth Heliothis virescens. Cell Tissue Res 327:385-398. CrossRef Medline

Berndt AJ, Tang JC, Ridyard MS, Lian T, Keatings K, Allan DW (2015) Gene regulatory mechanisms underlying the spatial and temporal regulation of target-dependent gene expression in Drosophila neurons. PLoS Genet 11:e1005754. CrossRef Medline

Binzer M, Heuer CM, Kollmann M, Kahnt J, Hauser F, Grimmelikhuijzen CJ, Schachtner J (2014) Neuropeptidome of Tribolium castaneum antennal lobes and mushroom bodies. J Comp Neur 522: 337-357. CrossRef Medline

Blackburn MB, Jaffe H, Kochansky J, Raina AK (2001) Identification of four additional myoinhibitory peptides (MIPs) from the ventral nerve cord of Manduca sexta. Arch Insect biochem Physiol 48: 121-128. CrossRef Medline

Bornhauser BC, Meyer EP (1997) Histamine-like immunoreactivity in the visual system and brain of an orthopteran and a hymenopteran insect. Cell Tissue Res 287:211-221. Medline

Bradley SP, Chapman PD, Lizbinski KM, Daly KC, Dacks AM (2016) A flight sensory-motor to olfactory processing circuit in the moth Manduca sexta. Front Neural Circ 10:5. CrossRef Medline

Bria A, lannello G, Onofri L, Peng H (2016) TeraFly: real-time 3D visualization and $3 \mathrm{D}$ annotation of terabytes of multidimensional volumetric images. Nat Methods 13:192-194. CrossRef

Cajal RS (1995) Histology of the nervous system of man and vertebrates. In: History of Neuroscience (2 Volume Set). Oxford: Oxford University Press.

Carlsson MA, Diesner M, Schachtner J, Nässel DR (2010) Multiple neuropeptides in the Drosophila antennal lobe suggest complex modulatory circuits. J Comp Neur 518:3359-3380. CrossRef Medline

Caron SJ, Ruta V, Abbott LF, Axel R (2013) Random convergence of olfactory inputs in the Drosophila mushroom body. Nature 497: 113-117. CrossRef Medline

Carroll LS, Carrow GM, Calabrese RL (1986) Localization and release of FMRFamide-like immunoreactivity in the cerebral neuroendocrine system of Manduca sexta. J Exp Biol 126:1-14. Medline

Chelaru MI, Dragoi V (2008) Efficient coding in heterogeneous neuronal populations. Proc Natl Acad Sci USA 105:16344-16349. CrossRef Medline
Chou YH, Spletter ML, Yaksi E, Leong JC, Wilson RI, Luo L (2010) Diversity and wiring variability of olfactory local interneurons in the Drosophila antennal lobe. Nat Neurosci 13:439-449. CrossRef Medline

Christ P, Reifenrath A, Kahnt J, Hauser F, Hill SR, Schachtner J, Ignell $R$ (2017) Feeding-induced changes in allatostatin-A and short neuropeptide $F$ in the antennal lobes affect odor-mediated host seeking in the yellow fever mosquito, Aedes aegypti. PloS One 12:e0188243. CrossRef Medline

Christensen TA, Hildebrand JG (1987) Male-specific, sex pheromone-selective projection neurons in the antennal lobes of the moth Manduca sexta. J Comp Physiol A Neuroethol Sens Neural Behav Physiol 160:553-569. Medline

Christensen TA, Waldrop BR, Harrow ID, Hildebrand JG (1993) Local interneurons and information processing in the olfactory glomeruli of the moth Manduca sexta. J Comp Physiol A Neuroethol Sens Neural Behav Physiol 173:385-399. Medline

Cohen JY, Amoroso MW, Uchida N (2015) Serotonergic neurons signal reward and punishment on multiple timescales. eLife 4:e06346. CrossRef

Croset V, Treiber CD, Waddell S (2018) Cellular diversity in the Drosophila midbrain revealed by single-cell transcriptomics. eLife 7:e34500.

Dacks AM, Reisenman CE, Paulk AC, Nighorn AJ (2010) Histamineimmunoreactive local neurons in the antennal lobes of the hymenoptera. J Comp Neur 518:2917-2933. CrossRef Medline

Daly KC, Kalwar F, Hatfield M, Staudacher E, Bradley SP (2013) Odor detection in Manduca sexta is optimized when odor stimuli are pulsed at a frequency matching the wing beat during flight. PloS One 8:e81863. CrossRef Medline

Das A, Sen S, Lichtneckert R, Okada R, Ito K, Rodrigues V, Reichert H (2008) Drosophila olfactory local interneurons and projection neurons derive from a common neuroblast lineage specified by the empty spiracles gene. Neural Dev 3:33. CrossRef Medline

Das A, Chiang A, Davla S, Priya R, Reichert H, Vijayraghavan K, Rodrigues $V$ (2011) Identification and analysis of a glutamatergic local interneuron lineage in the adult Drosophila olfactory system. Neural Syst Circuits 1:4. CrossRef

De Marco García NV, Karayannis T, Fishell G (2011) Neuronal activity is required for the development of specific cortical interneuron subtypes. Nature 472:351-355. CrossRef Medline

DeFelipe J, et al. (2013) New insights into the classification and nomenclature of cortical GABAergic interneurons. Nat Rev Neurosci 14:202-216. CrossRef Medline

Diesner M, Gallot A, Binz H, Gaertner C, Vitecek S, Kahnt J, Schachtner J, Jacquin-Joly E, Gadenne C (2018a) Mating-induced differential peptidomics of neuropeptides and protein hormones in Agrotis ipsilon moths. J Proteome Res 17:1397-1414.

Diesner M, Predel R, Neupert S (2018b) Neuropeptide mapping of dimmed cells of adult Drosophila brain. J Am Soc Mass Spectrom 29:890-902.

Distler PG, Boeckh J (1997) Synaptic connections between identified neuron types in the antennal lobe glomeruli of the cockroach, Periplaneta americana: II. Local multiglomerular interneurons. J Comp Neur 383:529-540. Medline

Eddine R, Valverde S, Tolu S, Dautan D, Hay A, Morel C, Cui Y, Lambolez B, Venance L, Marti F, Faure P (2015) A concurrent excitation and inhibition of dopaminergic subpopulations in response to nicotine. Scientific Reports 5:8184. CrossRef Medline

Elowitz MB, Levine AJ, Siggia ED, Swain PS (2002) Stochastic gene expression in a single cell. Science 297:1183-1186. CrossRef

Flames N, Marín O (2005) Developmental mechanisms underlying the generation of cortical interneuron diversity. Neuron 46:377381. CrossRef Medline

Flanagan D, Mercer A (1989) Morphology and response characteristics of neurones in the deutocerebrum of the brain in the honeybee Apis mellifera. J Comp Physiol A Neuroethol Sens Neural Behav Physiol 164:483-494. CrossRef 
Fonta C, Sun X, Masson C (1993) Morphology and spatial distribution of bee antennal lobe interneurones responsive to odours. Chem Senses 18:101-119. CrossRef

Fusca D, Husch A, Baumann A, Kloppenburg P (2013) Choline acetyltransferase-like immunoreactivity in a physiologically distinct subtype of olfactory nonspiking local interneurons in the cockroach (Periplaneta americana). J Comp Neur 521:3556-3569. CrossRef

Fusca D, Schachtner J, Kloppenburg P (2015) Colocalization of allatotropin and tachykinin-related peptides with classical transmitters in physiologically distinct subtypes of olfactory local interneurons in the cockroach (Periplaneta americana). J Comp Neur 523:1569-1586. CrossRef Medline

Gabitto MI, Pakman A, Bikoff JB, Abbott LF, Jessell TM, Paninski L (2016) Bayesian sparse regression analysis documents the diversity of spinal inhibitory interneurons. Cell 165:220-233. CrossRef Medline

Galizia CG, Kimmerle B (2004) Physiological and morphological characterization of honeybee olfactory neurons combining electrophysiology, calcium imaging and confocal microscopy. J Comp Physiol A Neuroethol Sens Neural Behav Physiol 190:21-38. CrossRef Medline

Gauthier SA, Hewes RS (2006) Transcriptional regulation of neuropeptide and peptide hormone expression by the Drosophila dimmed and cryptocephal genes. J Exp Biol 209:1803-1815. CrossRef Medline

Golgi C (1906) The neuron doctrine: theory and facts. Available at https://www.nobelprize.org/prizes/medicine/1906/golgi/lecture/

Gonchar Y, Wang Q, Burkhalter A (2007) Multiple distinct subtypes of GABAergic neurons in mouse visual cortex identified by triple immunostaining. Front Neuroanat 1:3. CrossRef

Hadzic T, Park D, Abruzzi KC, Yang L, Trigg JS, Rohs R, Rosbash M, Taghert PH (2015) Genome-wide features of neuroendocrine regulation in Drosophila by the basic helix-loop-helix transcription factor DIMMED. Nucleic Acids Res 43:2199-2215. CrossRef Medline

Hamanaka Y, Park D, Yin P, Annangudi SP, Edwards TN, Sweedler J, Meinertzhagen IA, Taghert PH (2010) Transcriptional orchestration of the regulated secretory pathway in neurons by the bHLH protein DIMM. Curr Biol 20:9-18. CrossRef Medline

Hewes RS, Gu T, Brewster JA, Qu C, Zhao T (2006) Regulation of secretory protein expression in mature cells by DIMM, a basic helix-loop-helix neuroendocrine differentiation factor. J Neurosci 26:7860-7869. CrossRef

Hewes RS, Park D, Gauthier SA, Schaefer AM, Taghert PH (2003) The bHLH protein Dimmed controls neuroendocrine cell differentiation in Drosophila. Development 130:1771-1781. Medline

Hildebrand JG, Christensen TA, Harrow ID, Homberg U, Matsumoto SG, Waldrop BR (1992) The roles of local interneurons in the processing of olfactory information in the antennal lobes of the moth Manduca sexta. Acta Biol Hung 43:167-174. Medline

Homberg U, Kingan TG, Hildebrand JG (1990) Distribution of FMRFamide-like immunoreactivity in the brain and suboesophageal ganglion of the sphinx moth Manduca sexta and colocalization with SCPB-, BPP-, and GABA-like immunoreactivity. Cell Tissue Res 259:401-419. Medline

Homberg U, Montague RA, Hildebrand JG (1988) Anatomy of antenno-cerebral pathways in the brain of the sphinx moth Manduca sexta. Cell Tissue Res 254:255-281. Medline

Honegger K, de Bivort B (2018) Stochasticity, individuality and behavior. Curr Biol 28:R8-R12. CrossRef Medline

Hong EJ, Wilson RI (2015) Simultaneous encoding of odors by channels with diverse sensitivity to inhibition. Neuron 85:573-589. CrossRef Medline

Horodyski FM, Verlinden H, Filkin N, Vandersmissen HP, Fleury C, Reynolds SE, Kai ZP, Broeck JV (2011) Isolation and functional characterization of an allatotropin receptor from Manduca sexta. Insect Biochem Mol Biol 41:804-814. CrossRef Medline

Hoskins SG, Homberg U, Kingan TG, Christensen TA, Hildebrand JG (1986) Immunocytochemistry of GABA in the antennal lobes of the sphinx moth Manduca sexta. Cell Tissue Res 244:243-252. Medline

Huang ZJ, Kirkwood A, Pizzorusso T, Porciatti V, Morales B, Bear MF, Maffei L, Tonegawa S (1999) BDNF regulates the maturation of inhibition and the critical period of plasticity in mouse visual cortex. Cell 98:739-755. Medline

Huh D, Paulsson J (2011) Non-genetic heterogeneity from stochastic partitioning at cell division. Nat Genet 43:95-100. CrossRef Medline

Husch A, Paehler M, Fusca D, Paeger L, Kloppenburg P (2009a) Calcium current diversity in physiologically different local interneuron types of the antennal lobe. J Neurosci 29:716-726. CrossRef

Husch A, Paehler M, Fusca D, Paeger L, Kloppenburg P (2009b) Distinct electrophysiological properties in subtypes of nonspiking olfactory local interneurons correlate with their cell type-specific $\mathrm{Ca} 2+$ current profiles. J Neurophysiol 102:2834-2845. CrossRef

Hussain A, Üçpunar HK, Zhang M, Loschek LF, Grunwald Kadow IC (2016) Neuropeptides modulate female chemosensory processing upon mating in Drosophila. PLoS Biol 14:e1002455. CrossRef Medline

Ignell R, Root CM, Birse RT, Wang JW, Nässel DR, Winther AM (2009) Presynaptic peptidergic modulation of olfactory receptor neurons in Drosophila. Proc Natl Acad Sci USA 106:13070-13075. CrossRef Medline

Jiang H, Wang Y, Kanost MR (1996) Primary structure of ribosomal proteins S3 and S7 from Manduca sexta. Insect Mol Biol 5:31-38. Medline

Kanost MR, et al. (2016) Multifaceted biological insights from a draft genome sequence of the tobacco hornworm moth, Manduca sexta. Insect Biochem Mol Biol 76:118-147. CrossRef Medline

Kepecs A, Fishell G (2014) Interneuron cell types are fit to function. Nature 505:318-326. CrossRef Medline

Ko KI, Root CM, Lindsay SA, Zaninovich OA, Shepherd AK, Wasserman SA, Kim SM, Wang JW (2015) Starvation promotes concerted modulation of appetitive olfactory behavior via parallel neuromodulatory circuits. eLife 4:e08298. CrossRef

Lenz O, Xiong J, Nelson MD, Raizen DM, Williams JA (2015) FMRFamide signaling promotes stress-induced sleep in Drosophila. Brain Behav Immun 47:141-148. CrossRef Medline

Li J, Xiao Y, Zhou W, Wu Z, Zhang R, Xu T (2009) Silence of synaptotagmin VII inhibits release of dense core vesicles in PC12 cells. Sci China Ser C Life Sci 52:1156-1163. CrossRef Medline

Li H, Horns F, Wu B, Xie Q, Li J, Li T, Luginbuhl DJ, Quake SR, Luo L (2017) Classifying Drosophila olfactory projection neuron subtypes by single-cell RNA sequencing. Cell 171:1206-1220.e1222.

Liang X, Holy TE, Taghert PH (2017) A series of suppressive signals within the Drosophila circadian neural circuit generates sequential daily outputs. Neuron 94:1173-1189.e1174. CrossRef

Liu WW, Wilson RI (2013) Glutamate is an inhibitory neurotransmitter in the Drosophila olfactory system. Proc Natl Acad Sci USA 110: 10294-10299. CrossRef Medline

Liu Y, Luo J, Nässel DR (2016) The Drosophila transcription factor Dimmed affects neuronal growth and differentiation in multiple ways depending on neuron type and developmental stage. Front Mol Neurosci 9:97. CrossRef Medline

Lizbinski KM, Metheny JD, Bradley SP, Kesari A, Dacks AM (2016) The anatomical basis for modulatory convergence in the antennal lobe of Manduca sexta. J Comp Neur 524:1859-1875. CrossRef Medline

Loesel R, Homberg U (1999) Histamine-immunoreactive neurons in the brain of the cockroach Leucophaea maderae. Brain Res 842: 408-418. Medline

Maccaferri G, Lacaille JC (2003) Interneuron diversity series: Hippocampal interneuron classifications-making things as simple as possible, not simpler. Trends Neurosci 26:564-571. CrossRef

Malun D (1991) Inventory and distribution of synapses of identified uniglomerular projection neurons in the antennal lobe of Periplaneta americana. J Comp Neur 305:348-360. CrossRef Medline

Marder E, Calabrese RL, Nusbaum MP, Trimmer B (1987) Distribution and partial characterization of FMRFamide-like peptides in the 
stomatogastric nervous systems of the rock crab, Cancer borealis, and the spiny lobster, Panulirus interruptus. J Comp Neur 259: 150-163. CrossRef Medline

Marsat G, Maler L (2010) Neural heterogeneity and efficient population codes for communication signals. J Neurophysiol 104:25432555. CrossRef Medline

Mayer C, Hafemeister C, Bandler RC, Machold R, Brito RB, Jaglin X, Allaway K, Butler A, Fishell G, Satija R (2018) Developmental diversification of cortical inhibitory interneurons. Nature 555:457462.

Min S, Chae HS, Jang YH, Choi S, Lee S, Jeong YT, Jones WD, Moon SJ, Kim YJ, Chung J (2016) Identification of a peptidergic pathway critical to satiety responses in Drosophila. Curr Biol 26: 814-820. CrossRef Medline

Nässel DR (2018) Substrates for neuronal cotransmission with neuropeptides and small molecule neurotransmitters in Drosophila. Front Cell Neurosci 12:83. CrossRef Medline

Nery S, Fishell G, Corbin JG (2002) The caudal ganglionic eminence is a source of distinct cortical and subcortical cell populations. Nat Neurosci 5:1279-1287. CrossRef Medline

Neupert S, Fusca D, Kloppenburg P, Predel R (2018) Analysis of single neurons by perforated patch clamp recordings and MALDITOF mass spectrometry. ACS Chem Neurosci 9:2089-2096. CrossRef Medline

Ng M, Roorda RD, Lima SQ, Zemelman BV, Morcillo P, Miesenböck $G$ (2002) Transmission of olfactory information between three populations of neurons in the antennal lobe of the fly. Neuron 36:463-474. Medline

Nusbaum MP, Blitz DM, Marder E (2017) Functional consequences of neuropeptide and small-molecule co-transmission. Nat Rev Neurosci 18:389-403. CrossRef Medline

Nusbaum MP, Blitz DM, Swensen AM, Wood D, Marder E (2001) The roles of co-transmission in neural network modulation. Trends Neurosci 24:146-154. Medline

Ogawa T, Riera J, Goto T, Sumiyoshi A, Nonaka H, Jerbi K, Bertrand O, Kawashima R (2011) Large-scale heterogeneous representation of sound attributes in rat primary auditory cortex: from unit activity to population dynamics. J Neurosci 31:14639-14653. CrossRef

Okaty BW, Freret ME, Rood BD, Brust RD, Hennessy ML, deBairos D, Kim JC, Cook MN, Dymecki SM (2015) Multi-scale molecular deconstruction of the serotonin neuron system. Neuron 88:774791. CrossRef Medline

Olsen SR, Wilson RI (2008) Lateral presynaptic inhibition mediates gain control in an olfactory circuit. Nature 452:956-960. CrossRef

Ormerod KG, Krans JL, Mercier AJ (2015) Cell-selective modulation of the Drosophila neuromuscular system by a neuropeptide. J Neurophysiol 113:1631-1643. CrossRef Medline

Park D, Veenstra JA, Park JH, Taghert PH (2008a) Mapping peptidergic cells in Drosophila: where DIMM fits in. PloS One 3:e1896. CrossRef Medline

Park D, Shafer OT, Shepherd SP, Suh H, Trigg JS, Taghert PH (2008b) The Drosophila basic helix-loop-helix protein DIMMED directly activates PHM, a gene encoding a neuropeptideamidating enzyme. Mol Cell Biol 28:410-421. CrossRef

Park D, Taghert PH (2009) Peptidergic neurosecretory cells in insects: organization and control by the bHLH protein DIMMED. Gen Compar Endocrinol 162:2-7. CrossRef Medline

Park D, Li P, Dani A, Taghert PH (2014) Peptidergic cell-specific synaptotagmins in Drosophila: localization to dense-core granules and regulation by the bHLH protein DIMMED. J Neurosci 34: 13195-13207. CrossRef

Patz S, Grabert J, Gorba T, Wirth MJ, Wahle P (2004) Parvalbumin expression in visual cortical interneurons depends on neuronal activity and TrkB ligands during an early period of postnatal development. Cereb Cortex 14:342-351. Medline

Peng H, Ruan Z, Long F, Simpson JH, Myers EW (2010) V3D enables real-time 3D visualization and quantitative analysis of large-scale biological image data sets. Nat Biotechnol 28:348-353. CrossRef Medline
Peng H, Bria A, Zhou Z, lannello G, Long F (2014a) Extensible visualization and analysis for multidimensional images using Vaa3D. Nat Prot 9:193-208. Retrieved from http://vaa3d.org/

Peng H, Tang J, Xiao H, Bria A, Zhou J, Butler V, Zhou Z, GonzalezBellido PT, Oh SW, Chen J, Mitra A, Tsien RW, Zeng H, Ascoli GA, lannello G, Hawrylycz M, Myers E, Long F (2014b) Virtual finger boosts three-dimensional imaging and microsurgery as well as terabyte volume image visualization and analysis. Nat Comm 5:4342. CrossRef

Pitkow X, Meister M (2012) Decorrelation and efficient coding by retinal ganglion cells. Nat Neurosci 15:628-635. CrossRef Medline

Pratt GE, Farnsworth DE, Fok KF, Siegel NR, McCormack AL, Shabanowitz J, Hunt DF, Feyereisen R (1991) Identity of a second type of allatostatin from cockroach brains: an octadecapeptide amide with a tyrosine-rich address sequence. Proc Natl Acad Sci USA 88:2412-2416. Medline

Predel R, Rapus J, Eckert M (2001) Myoinhibitory neuropeptides in the American cockroach. Peptides 22:199-208. Medline

Raj A, van Oudenaarden A (2008) Nature, nurture, or chance: stochastic gene expression and its consequences. Cell 135:216-226. CrossRef Medline

Ramón y, Cajal Santiago (1972) The structure of the retina. Translated by SA Thorpe and M. Glickstein. Springfield, Illinois: CC Thomas.

Reichwald K, Unnithan GC, Davis NT, Agricola H, Feyereisen R (1994) Expression of the allatostatin gene in endocrine cells of the cockroach midgut. Proc Natl Acad Sci USA 91:11894-11898. Medline

Reisenman CE, Dacks AM, Hildebrand JG (2011) Local interneuron diversity in the primary olfactory center of the moth Manduca sexta. J Comp Physiol A Neuroethol Sens Neural Behav Physiol 197:653-665. CrossRef Medline

Root CM, Masuyama K, Green DS, Enell LE, Nässel DR, Lee CH, Wang JW (2008) A presynaptic gain control mechanism fine-tunes olfactory behavior. Neuron 59:311-321. CrossRef Medline

Salio C, Lossi L, Ferrini F, Merighi A (2006) Neuropeptides as synaptic transmitters. Cell Tissue Res 326:583-598. CrossRef Medline

Saraswati S, Adolfsen B, Littleton JT (2007) Characterization of the role of the Synaptotagmin family as calcium sensors in facilitation and asynchronous neurotransmitter release. Proc Natl Acad Sci USA 104:14122-14127. CrossRef Medline

Schachtner J, Trosowski B, D'Hanis W, Stubner S, Homberg U (2004) Development and steroid regulation of RFamide immunoreactivity in antennal-lobe neurons of the sphinx moth Manduca sexta. J Exp Biol 207:2389-2400. CrossRef Medline

Schäfer S, Bicker G (1986) Distribution of GABA-like immunoreactivity in the brain of the honeybee. J Comp Neur 246:287-300. CrossRef Medline

Seidel C, Bicker G (1997) Colocalization of NADPH-diaphorase and GABA-immunoreactivity in the olfactory and visual system of the locust. Brain Res 769:273-280. Medline

Shepherd GM (2015) Foundations of the neuron doctrine. Oxford: Oxford University Press.

Siju KP, Reifenrath A, Scheiblich H, Neupert S, Predel R, Hansson BS, Schachtner J, Ignell R (2014) Neuropeptides in the antennal lobe of the yellow fever mosquito, Aedes aegypti. J Comp Neur 522:592-608.

Skaer NJ, Nässel DR, Maddrell SH, Tublitz NJ (2002) Neurochemical fine tuning of a peripheral tissue: peptidergic and aminergic regulation of fluid secretion by Malpighian tubules in the tobacco hawkmoth M. sexta. J Exp Biol 205:1869-1880. Medline

Stratmann J, Thor S (2017) Neuronal cell fate specification by the molecular convergence of different spatio-temporal cues on a common initiator terminal selector gene. PLoS Genet 13: e1006729. CrossRef Medline

Sun X, Fonta C, Masson C (1993) Odour quality processing by bee antennal lobe interneurones. Chem Senses 18:355-377. CrossRef Sweeney LB, Bikoff JB, Gabitto MI, Brenner-Morton S, Baek M, Yang JH, Tabak EG, Dasen JS, Kintner CR, Jessell TM (2018) 
Origin and segmental diversity of spinal inhibitory interneurons. Neuron 97:341-355.e343. CrossRef

Teal PE (2002) Effects of allatotropin and allatostatin on in vitro production of juvenile hormones by the corpora allata of virgin females of the moths of Heliothis virescens and Manduca sexta. Peptides 23:663-669. Medline

Tritsch NX, Granger AJ, Sabatini BL (2016) Mechanisms and functions of GABA co-release. Nat Rev Neurosci 17:139-145. CrossRef Medline

Utz S, Schachtner J (2005) Development of A-type allatostatin immunoreactivity in antennal lobe neurons of the sphinx moth Manduca sexta. Cell Tissue Res 320:149-162. CrossRef Medline

Utz S, Huetteroth W, Vömel M, Schachtner J (2008) Mas-allatotropin in the developing antennal lobe of the sphinx moth Manduca sexta: distribution, time course, developmental regulation, and colocalization with other neuropeptides. Dev Neurobiol 68:123142. CrossRef Medline

Utz S, Huetteroth W, Wegener C, Kahnt J, Predel R, Schachtner J (2007) Direct peptide profiling of lateral cell groups of the antennal lobes of Manduca sexta reveals specific composition and changes in neuropeptide expression during development. Dev Neurobiol 67:764-777. CrossRef Medline
Veenstra JA, Hagedorn HH (1995) Isolation of two AKH-related peptides from cicadas. Arch Insect Biochem Physiol 29:391-396. CrossRef Medline

Wichterle H, Turnbull DH, Nery S, Fishell G, Alvarez-Buylla A (2001) In utero fate mapping reveals distinct migratory pathways and fates of neurons born in the mammalian basal forebrain. Development 128:3759-3771. Medline

Wilson RI (2013) Early olfactory processing in Drosophila: mechanisms and principles. Ann Rev Neurosci 36:217-241. CrossRef Medline

Wilson RI, Laurent G (2005) Role of GABAergic inhibition in shaping odor-evoked spatiotemporal patterns in the Drosophila antennal lobe. J Neurosci 25:9069-9079. CrossRef

Witten JL, Truman JW (1996) Developmental plasticity of neuropeptide expression in motoneurons of the moth, Manduca sexta: steroid hormone regulation. J Neurobiol 29:99-114. CrossRef Medline

Yapici N, Kim YJ, Ribeiro C, Dickson BJ (2008) A receptor that mediates the post-mating switch in Drosophila reproductive behaviour. Nature 451:33-37. CrossRef Medline

Yavorska I, Wehr M (2016) Somatostatin-expressing inhibitory interneurons in cortical circuits. Front Neural Circ 10:76. CrossRef Medline 